University of Nebraska - Lincoln

DigitalCommons@University of Nebraska - Lincoln

\title{
Holocene multidecadal and multicentennial droughts affecting Northern California and Nevada
}

\author{
Larry Benson \\ U.S. Geological Survey, great.basin666@gmail.com \\ Michaele Kashgarian \\ Lawrence Livemore National Laboratory \\ Robert Rye \\ U.S. Geological Survey \\ Steve Lund \\ University of Southern California, slund@usc.edu \\ Fred Paillet \\ U.S. Geological Survey
}

See next page for additional authors

Follow this and additional works at: https://digitalcommons.unl.edu/usgsstaffpub

Part of the Earth Sciences Commons

\begin{abstract}
Benson, Larry; Kashgarian, Michaele; Rye, Robert; Lund, Steve; Paillet, Fred; Smoot, Joseph; Kester, Cynthia; Mensing, Scott; Meko, Dave; and Landström, Susan, "Holocene multidecadal and multicentennial droughts affecting Northern California and Nevada" (2002). USGS Staff -- Published Research. 365. https://digitalcommons.unl.edu/usgsstaffpub/365
\end{abstract}

This Article is brought to you for free and open access by the US Geological Survey at DigitalCommons@University of Nebraska - Lincoln. It has been accepted for inclusion in USGS Staff -- Published Research by an authorized administrator of DigitalCommons@University of Nebraska - Lincoln. 


\section{Authors}

Larry Benson, Michaele Kashgarian, Robert Rye, Steve Lund, Fred Paillet, Joseph Smoot, Cynthia Kester, Scott Mensing, Dave Meko, and Susan Landström 


\title{
Holocene multidecadal and multicentennial droughts affecting Northern California and Nevada
}

\author{
Larry Benson ${ }^{\mathrm{a}, *}$, Michaele Kashgarian ${ }^{\mathrm{b}}$, Robert Rye ${ }^{\mathrm{c}}$, Steve Lund ${ }^{\mathrm{d}}$, Fred Paillet ${ }^{\mathrm{e}}$, \\ Joseph Smoot ${ }^{\mathrm{f}}$, Cynthia Kester ${ }^{\mathrm{c}}$, Scott Mensing ${ }^{\mathrm{g}}$, Dave Meko ${ }^{\mathrm{h}}$, Susan Lindström ${ }^{\mathrm{i}}$ \\ ${ }^{a}$ US Geological Survey, 3215 Marine Street, Boulder, CO 80303, USA \\ ${ }^{\mathrm{b}}$ Lawrence Livermore National Laboratory, PO Box 808, Livermore, CA 94550, USA \\ ${ }^{\mathrm{c}}$ US Geological Survey, MS 963, Denver Federal Center, Lakewood, CO 80225, USA \\ ${ }^{\mathrm{d}}$ Department of Earth Sciences, University of Southern California, Los Angeles, CA 90089, USA \\ ${ }^{\mathrm{e}}$ US Geological Survey, MS 403, Denver Federal Center, Lakewood, CO 80225, USA \\ ${ }^{\mathrm{f}}$ US Geological Survey, MS 955, Reston VA 22092, USA \\ ${ }^{g}$ Department of Geography, University of Nevada, Reno, NV 89557, USA \\ ${ }^{\mathrm{h}}$ Laboratory of Tree-Ring Research, University of Arizona, Tucson, AZ 85721, USA
}

${ }^{i}$ Box 324, Truckee, CA 95734, USA

\begin{abstract}
Continuous, high-resolution $\delta^{18} \mathrm{O}$ records from cored sediments of Pyramid Lake, Nevada, indicate that oscillations in the hydrologic balance occurred, on average, about every 150 years (yr) during the past 7630 calendar years (cal yr). The records are not stationary; during the past $2740 \mathrm{yr}$, drought durations ranged from 20 to $100 \mathrm{yr}$ and intervals between droughts ranged from 80 to $230 \mathrm{yr}$. Comparison of tree-ring-based reconstructions of climate change for the past $1200 \mathrm{yr}$ from the Sierra Nevada and the El Malpais region of northwest New Mexico indicates that severe droughts associated with Anasazi withdrawal from Chaco Canyon at 820 cal yr BP (calendar years before present) and final abandonment of Chaco Canyon, Mesa Verde, and the Kayenta area at 650 cal yr BP may have impacted much of the western United States.During the middle Holocene (informally defined in this paper as extending from 8000 to 3000 cal yr BP), magnetic susceptibility values of sediments deposited in Pyramid Lake's deep basin were much larger than late-Holocene $\left(3000-0\right.$ cal yr BP) values, indicating the presence of a shallow lake. In addition, the mean $\delta^{18} \mathrm{O}$ value of $\mathrm{CaCO}_{3}$ precipitated between 6500 and 3430 cal yr BP was $1.6 \%$ less than the mean value of $\mathrm{CaCO}_{3}$ precipitated after $2740 \mathrm{cal}$ yr BP. Numerical calculations indicate that the shift in the $\delta^{18} \mathrm{O}$ baseline probably resulted from a transition to a wetter $(>30 \%)$ and cooler $\left(3-5^{\circ} \mathrm{C}\right)$ climate. The existence of a relatively dry and warm middle-Holocene climate in the Truckee RiverPyramid Lake system is generally consistent with archeological, sedimentological, chemical, physical, and biological records from various sites within the Great Basin of the western United States. Two high-resolution Holocene-climate records are now available from the Pyramid and Owens lake basins which suggest that the Holocene was characterized by five climatic intervals. TIC and $\delta^{18} \mathrm{O}$ records from Owens Lake indicate that the first interval in the early Holocene $(11,600-10,000$ cal yr BP) was characterized by a drying trend that was interrupted by a brief ( $200 \mathrm{yr}$ ) wet oscillation centered at 10,300 cal yr BP. This was followed by a second earlyHolocene interval (10,000-8000 cal yr BP) during which relatively wet conditions prevailed. During the early part of the middle Holocene (8000-6500 cal yr BP), high-amplitude oscillations in TIC in Owens Lake and $\delta^{18} \mathrm{O}$ in Pyramid Lake indicate the presence of shallow lakes in both basins. During the latter part of the middle Holocene (6500-3800 cal yr BP), drought conditions dominated, Owens Lake desiccated, and Lake Tahoe ceased spilling to the Truckee River, causing Pyramid Lake to decline. At the beginning of the late Holocene $(\sim 3000$ cal yr BP), Lake Tahoe rose to its sill level and Pyramid Lake increased in volume. C) 2002 Elsevier Science Ltd. All rights reserved.
\end{abstract}

\footnotetext{
*Corresponding author. Tel.: +1-303-541-3005; fax: + 1-303-4472505.

E-mail address: 1benson@usgs.gov (L. Benson).
}

\section{Introduction}

From the perspective of the Greenland ice-core records, the onset of the Holocene occurred $\sim 11,600$ cal yr BP with the termination of the Younger Dryas cold interval (Alley, 2000). Within North America, the Holocene has generally been assigned a 
tripartite structure with the middle Holocene being generally warmer or drier than the early and late Holocene. Because climate does not evolve synchronously throughout North America, the boundaries between the three intervals differ from region to region. For the purposes of this paper, the middle Holocene is considered to have occurred within the Great Basin between approximately 8000 and 3000 cal yr BP.

In this paper we use the word drought in a variety of ways. For the historical period (the last $100 \mathrm{yr}$ ), drought indicates times when water shortage adversely affected human populations. For the late Holocene (the last $3000 \mathrm{yr}$ ), drought in the Truckee River-Pyramid Lake surface-water system indicates times of persistent lakesize decline. And for the middle Holocene, drought signifies times when Lake Tahoe did not overflow.

During the 1930s, severe drought impacted the western and mid-continental United States (Hecht, 1983; Woodhouse and Overpeck, 1998), generating great concern regarding the frequency and duration of such events. In the Sierra Nevada and the Great Basin of the arid West, climate records were extended by dating stumps of submerged trees that had taken root during drier times (Harding, 1935; Lawrence and Lawrence, 1961; Harding, 1965) and by using tree-ring widths to reconstruct records of prehistoric river discharge (Hardman and Reil, 1936). Droughts have reoccurred since the late 1930s but it was not until the late 1980s and early 1990s that prolonged drought once again affected the Sierra Nevada, as evidenced by hydrologic closure of Lake Tahoe and persistent below-average discharge of the Truckee River (Fig. 1).

Seven years of drought within an 8-yr period (19871994) (Fig. 1) spawned renewed interest in the history

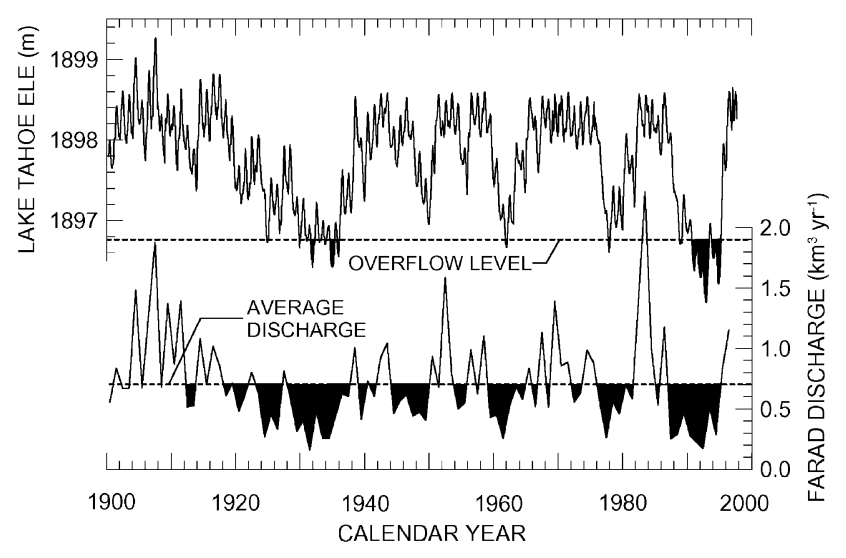

Fig. 1. Annual discharge of the Truckee River at Farad, California, and monthly elevation of Lake Tahoe at Tahoe City, California, since 1900. Only minor consumptive losses of Truckee River water occur upstream of the Farad gage (Fig. 5). Solid areas in top panel indicate times that Lake Tahoe did not overflow to the Truckee River. Solid areas in lower panel indicate times when flow of the Truckee was less than the historical mean-annual rate of $0.70 \mathrm{~km}^{3} \mathrm{yr}^{-1}$. Note that most minima in lake level correspond to minima in discharge rates. and prehistory of such events. Recent tree-ring reconstructions, employing sophisticated statistical calibrations, have extended Sierra Nevada and Great Basin precipitation and discharge records back more than a $1000 \mathrm{yr}$ (Graumlich, 1993; Hughes and Funkhouser, 1998; Meko et al., 1999) and AMS ${ }^{14} \mathrm{C}$ studies of stumps from Sierran lakes have highlighted severe droughts that terminated about 840 and $600 \mathrm{calyr}$ BP (Stine 1990, 1994).

During the 1930s drought, Harding observed 11 rooted stumps which had been exposed by receding water along the south shore of Lake Tahoe. Harding (1965) later reported ${ }^{14} \mathrm{C}$ ages of two of these stumps rooted at elevations $\sim 9 \mathrm{~cm}$ below that of the natural sill of Lake Tahoe (1896.8 m). One stump yielded dates of $4250 \pm 200$ and $4790 \pm 200{ }^{14} \mathrm{Cyr} \mathrm{BP}$, and the other stump yielded a date of $4460 \pm 250{ }^{14} \mathrm{C}$ yr BP. Harding (1965) was not able to determine if the submerged stumps were the result of drier climate or tectonics, stating that "...the age of these stumps is sufficiently long to include time enough for climate changes and orographic movement". In a later section of this paper we show that $\delta^{18} \mathrm{O}$ and magnetic susceptibility data from Pyramid Lake sediments indicate that Lake Tahoe remained below its overflow level during much of the middle Holocene.

Between 1989 and 1992, Lindström (1990) located 20 more stumps along the south side of Lake Tahoe. Some of the stumps reach depths as much as $4 \mathrm{~m}$ below sill level, and ${ }^{14} \mathrm{C}$ ages from 14 of the stumps range from $5510 \pm 90$ to $4240 \pm 200{ }^{14} \mathrm{C}$ yr BP $(6290-4840$ cal yr BP) (Fig. 2).

There are additional indicators of climate change that point toward a relatively dry middle Holocene in the Great Basin. Thompson (1992) showed that between 7660 and $5450 \mathrm{cal}$ yr BP sedimentation rates in the Ruby Marshes of western Nevada decreased by a factor of three, relative to the late Holocene, indicating either a lowered deposition rate or sediment deflation. In either case, the data suggest a drier middle-Holocene. More recently, Grayson (2000), using a well-dated small mammal sequence from Homestead Cave, Utah, has shown that faunas underwent a decrease in species richness in the middle Holocene in response to more xeric conditions. For example, the decreasing abundance of harvest mice between 9200 and $\sim 3500$ ca$1 \mathrm{yr} \mathrm{BP}$ indicates a much drier climate than during the early and late Holocene (Grayson, 2000). Farther south in the Great Basin, black mats, formed by spring discharge to wet meadows and shallow ponds, are absent from 7250 to $2500 \mathrm{calyr} \mathrm{BP}$, also indicating a period of relative aridity (Quade et al., 1998).

Data from lakes fed by Sierran streams also provide evidence of middle-Holocene dryness. The onset of a generally drier climate in the Owens Lake basin, characterized by abrupt oscillations in TIC and $\delta^{18} \mathrm{O}$, 


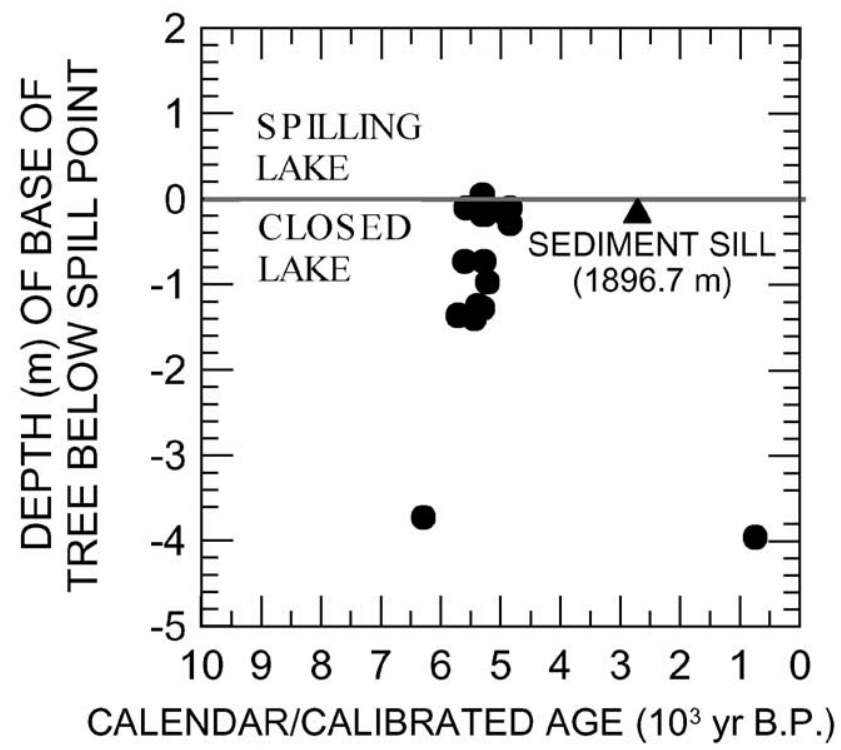

Fig. 2. Age-depth relationships of radiocarbon-dated tree stumps located at or below the natural (sediment) sill level of Lake Tahoe, California. Most of the data were taken from Lindström (1990). Three samples from Baldwin Beach $\left(4250 \pm 200{ }^{14} \mathrm{Cyr} \mathrm{BP}, 1896.41 \mathrm{~m}\right.$, Beta 56632), and Trout Creek delta $\left(4480 \pm 60{ }^{14} \mathrm{Cyr} \mathrm{BP}, 1895.82 \mathrm{~m}\right.$, Beta 90208; $4590 \pm 60{ }^{14} \mathrm{C}$ yr BP, $1895.52 \mathrm{~m}$, Beta 90207) were previously unpublished. Note that the death of a stump as indicated by the ${ }^{14} \mathrm{C}$ age of its outer rings pinpoints the timing of a rise in Lake Tahoe; e.g., a rising lake at $\sim 6290$ cal yr BP killed the oldest stump.

began at 7700 cal yr BP and ended $\sim 3200$ cal yr BP (Fig. 3). A sediment hiatus between 6480 and $3930 \mathrm{cal}$ yr BP suggests that that the lake had desiccated or was below the elevation of the core site during this time (Benson et al., 1997, 2001). It is possible that deflation removed sediment from the lakebed after the lake desiccated, implying that the age of the sediment on the bottom of the hiatus represents a maximum estimation of the beginning of the desiccation. On the other hand, it is also possible that a thick salt formed over the lakebed in this part of the basin as it has in the historical period, preventing sediment deflation. Data from a sediment core taken from Walker Lake, Nevada, indicate that it desiccated at or before $5030 \mathrm{cal} \mathrm{yr} \mathrm{BP}$ (assuming a 300-yr reservoir effect, Benson et al., 1991).

A warmer middle Holocene has also been inferred from various climate indicators. In the Sheep Mountain area located on the east slope of the White Mountains of California, tree-line elevations were relatively high between $>5700$ and $4100 \mathrm{calyr}$ BP. The tree line fell $100 \mathrm{~m}$ between 4100 and $3500 \mathrm{cal}$ yr BP, implying a $1^{\circ} \mathrm{C}$ decrease in warm-season temperatures (La Marche, 1973). Tree line fell another $70 \mathrm{~m} \sim 900 \mathrm{cal} \mathrm{yr} \mathrm{BP}$, indicating an additional $0.7^{\circ} \mathrm{C}$ decrease in air temperature. Grayson (1993) has shown that pikas, which cannot bear the heat of desert environments, disappeared from low-elevation sites throughout the Great Basin $7850 \mathrm{calyr}$ BP. Montane species of plants are

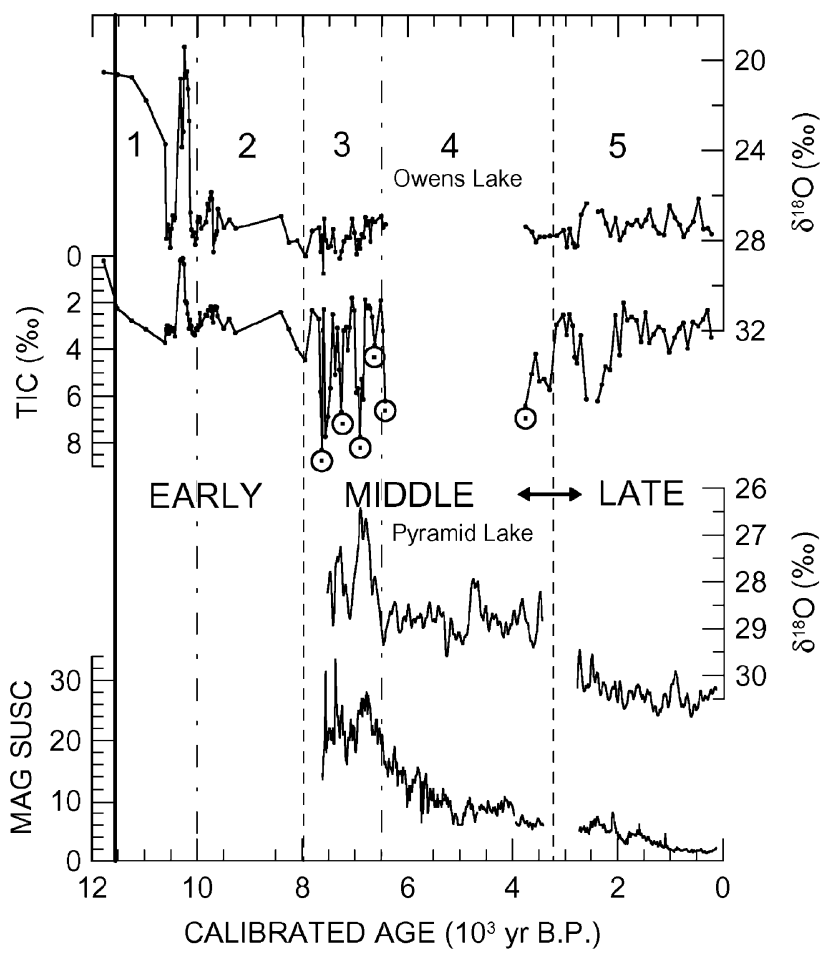

Fig. 3. TIC and $\delta^{18} \mathrm{O}$ records from Owens Lake core OL84B since $11,600 \mathrm{cal} y \mathrm{BP}$ and $\delta^{18} \mathrm{O}$ and magnetic susceptibility records from Pyramid Lake since 7630 cal yr BP. Data used in the construction of the Owens Lake records were taken from Benson et al. (2001). The data sets indicate that the Holocene of the western Great Basin can be divided into five distinct climatic intervals.

common in middens from the eastern Great Basin before $\sim 7400 \mathrm{cal} \mathrm{yr} \mathrm{BP}$, whereas younger assemblages are dominated by plant species that point to a rise in summer temperatures, perhaps coupled with an increase in summer rainfall (Thompson, 1990).

Middle-Holocene aridity also appears to have affected indigenous populations. Textile dates from archeological sites located in the western Great Basin suggest that few people inhabited rock shelters between 10,000 and 2500 cal yr BP (Fig. 4). Distributions of this type, with a characteristically low middle-Holocene site occupation, are common in the Great Basin (Grayson, 1993, 2000).

The various climate indicators show that Great Basin middle-Holocene climate was characterized by warmer summers and aridity. However, the timing of the middle-Holocene warm/dry period appears to vary with site location and with the type of climate indicator, a subject we will return to later. We also hasten to point out that the middle Holocene was not always dry. There is evidence for wet periods during the middle Holocene from the Lahontan basin, the Mono Lake basin, and from Diamond Pond. Kramer Cave is part of the Falcon Hill archeologic site located at the northwestern edge of the Winnemucca Lake basin. Ten radiocarbon dates ranging from $3900 \pm 100$ to $3620 \pm 30{ }^{14} \mathrm{C} \mathrm{yr} \mathrm{BP}$ 


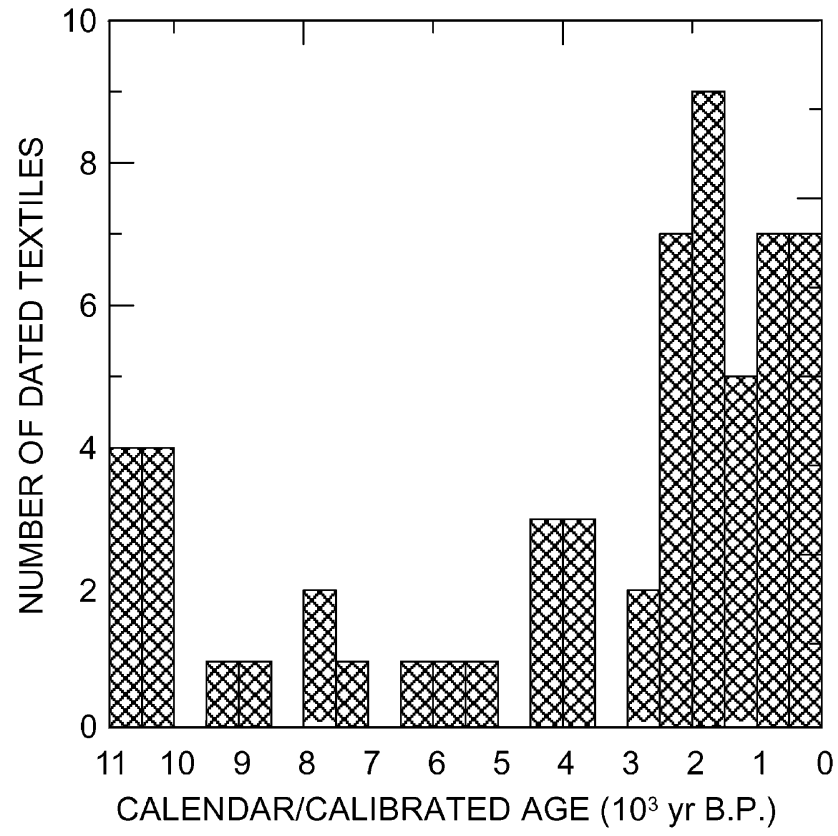

Fig. 4. Histogram of dates on archaeological textiles from the western Great Basin (from data base compiled by Susan McCabe and Eugene Hattori). Multiple dates on samples from a single time horizon have been eliminated.

( 4320-3920 cal yr BP) were obtained on artifacts recovered from the deposits (Long and Rippeteau, 1974). Included within the deposits were fish vertebrae (cui-ui and cutthroat trout) and the remains of western pond turtles, indicating that the Winnemucca Lake basin held water at this time (Hattori, 1982). Spikes in cattail pollen found in Hidden Cave between 3800 and $3600{ }^{14} \mathrm{C}$ yr BP $\quad(4160-3880$ cal yr BP) (Wigand and Mehringer, 1985) may attest to the presence of nearby marshes and deepening of lakes in the Lahontan Basin's Carson Sink at this time (Grayson, 1993). There is also an increase in the number of archeological textiles between 4500 and $3500 \mathrm{cal}$ yr BP in the western Great Basin, suggesting an increase in indigenous populations (Fig. 4). Evidence for an extremely wet period in the Mono Lake basin also occurs at this time (the Dechambeau Ranch highstand, 3770 cal yr BP) (Stine, 1990a, b). In addition, Diamond Pond in southeastern Oregon experienced a sharp increase in aquatic plant seeds between 3720 and $3480{ }^{14} \mathrm{Cyr} \mathrm{BP}$ (4010 and 3700 cal yr BP) (Wigand, 1987).

\section{The Truckee River-Pyramid Lake system}

In this paper we discuss a 7630-yr record of climate change from Pyramid Lake Nevada. Pyramid Lake was selected as a study site for several reasons:

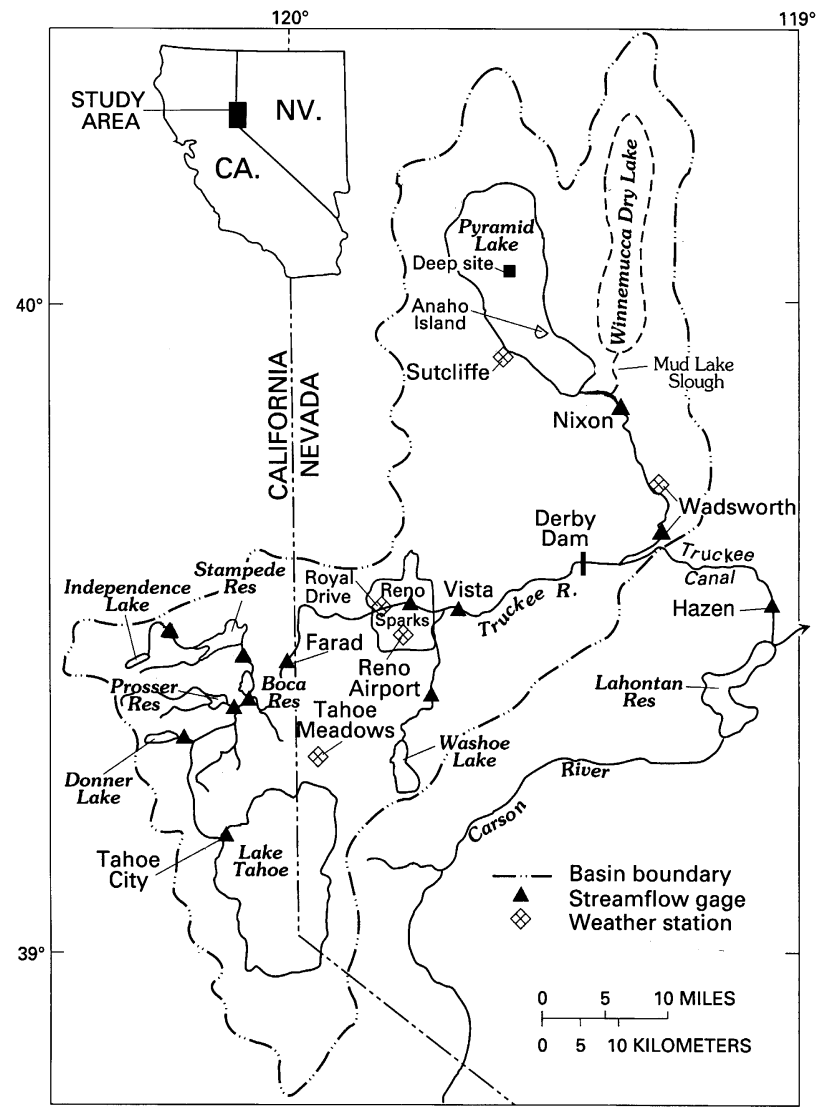

Fig. 5. Location map of the Lake Tahoe and Truckee River-Pyramid Lake surface-water system. Greater than $90 \%$ of the Truckee River input to Pyramid Lake occurs above the Farad, California, gage. Since 1906 , diversion of $\sim 54 \%$ of the flow of the Truckee River has occurred via the Derby Dam.

\subsection{Pyramid Lake is part of a relatively simple hydrologic system}

The Truckee River (watershed area $=7050 \mathrm{~km}^{2}$ ) represents the principal input of water to Pyramid Lake (Fig. 5). Cold-season precipitation falling in the Sierra Nevada is released to the Truckee River surface-water system as snowmelt in the spring and early summer. Approximately $32 \%$ of Truckee River flow reaching the Farad gage in eastern California emanates from Lake Tahoe and $38 \%$ of Truckee River flow reaching the Farad gage passes through small-capacity reservoirs. The remaining $30 \%$ of the flow enters the river as overland flow (Benson, 1994a, b). Above Farad the Truckee River is largely unaffected by diversion and downstream contributions of water are small. Groundwater input to Pyramid Lake is negligible and prior to 1918 overflow to Winnemucca Lake occurred frequently.

In 1906, Derby Dam located $53 \mathrm{~km}$ upstream of Pyramid Lake was completed. Since that time an average of $54 \%$ of Truckee River flow has been diverted 
from the Truckee River basin causing the level of Pyramid Lake to rapidly decline (Fig. 6). Because of the drop in lake level Pyramid Lake has not overflowed to the Winnemucca Lake basin since 1917; it has remained hydrologically closed for the past $83 \mathrm{yr}$. Hydrologic modeling of the Truckee River-Pyramid Lake surfacewater system indicates, however, that Pyramid Lake would not have fallen more than $3.5 \mathrm{~m}$ below its spill elevation $(1177 \mathrm{~m})$ during the past $100 \mathrm{yr}$ if water had not been diverted from the Truckee River system (Fig. 7).

\subsection{Information on change in the hydrologic balance of Pyramid Lake is transferable to rivers that drain both flanks of the northern Sierra Nevada}

Annual discharges of rivers that head in the Sierra Nevada correlate because they derive their water from the same snow pack (Table 1) (Fig. 8). This correlation weakens, however, as the north-south distance between rivers increases, indicating the presence of a climatic gradient. This gradient is due to two processes: the coldseason precipitation regime (winter cyclones) exhibits a seasonal southward progression whose latitudinal extent differs from year to year (Pyke, 1972), and precipitation during ENSO years exerts a stronger and more consistent influence on the southern Sierra Nevada (Redmond and Koch, 1991; Cayan et al., 1999; McCabe and Dettinger, 1999).

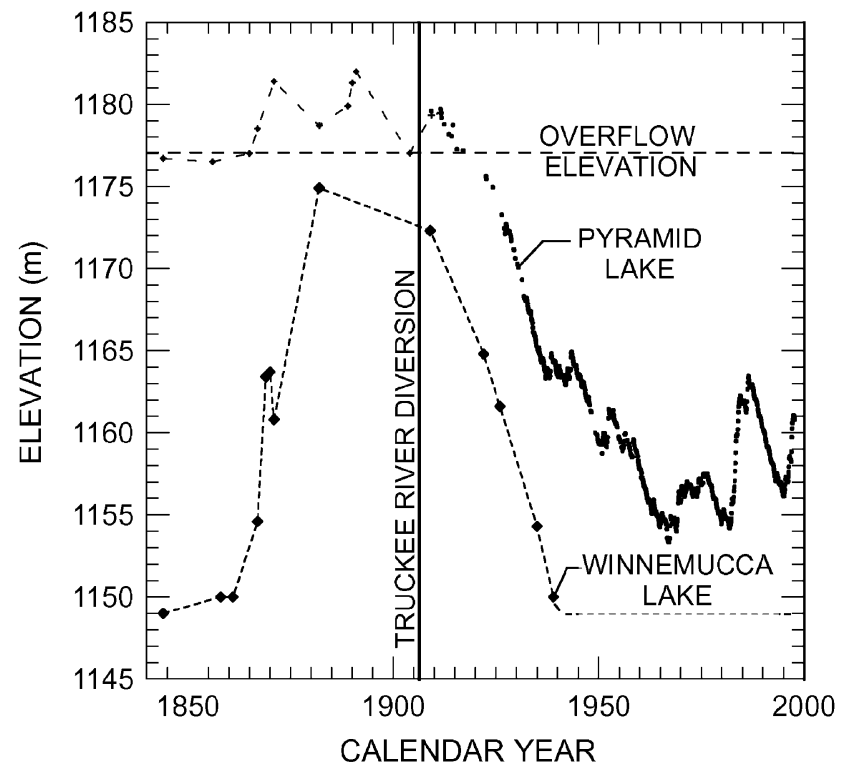

Fig. 6. Elevation of Pyramid and Winnemucca lakes since 1844. Diversions from the Truckee River began about 1860 and were accelerated after the completion of the Derby Dam and Truckee Canal in 1906. As a result of the diversions, Winnemucca Lake, which frequently received spill from Pyramid Lake, desiccated in $\sim 1938$. Pyramid has not overflowed since 1917.
If changes in Truckee River discharge can be estimated for the Holocene, such changes can be linked to discharges of rivers that drain both the east and west slopes of the northern Sierra Nevada. A study of variation in the size of Pyramid Lake is pertinent because volume fluctuations of Pyramid Lake are related to Truckee River discharge (Fig. 9).

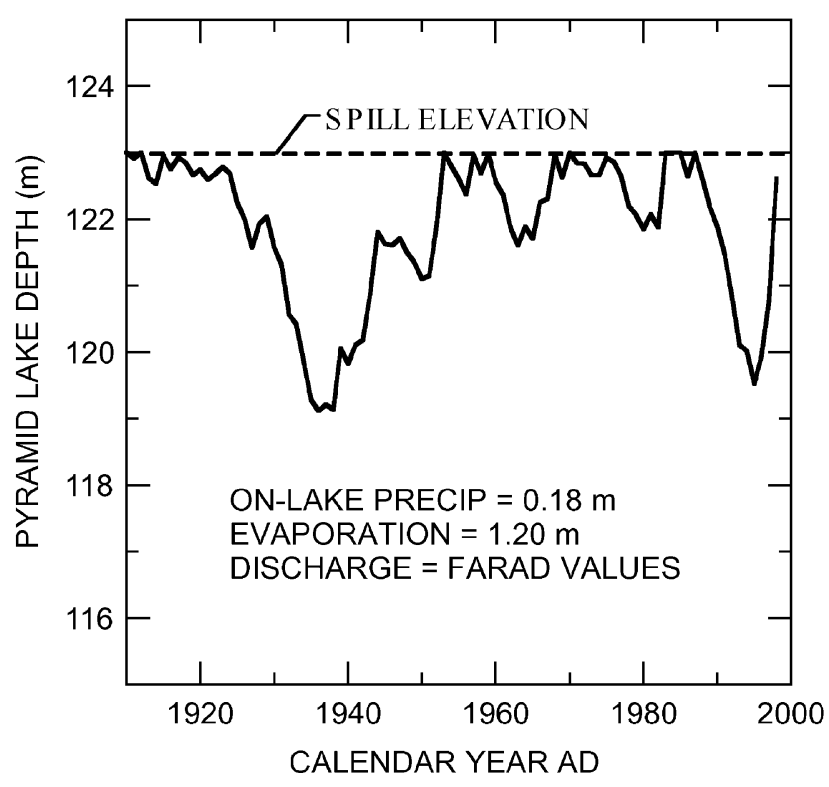

Fig. 7. Reconstruction of the pristine elevation of Pyramid Lake since 1910. Annual values of Truckee River discharge for the Farad, California, gage (Fig. 5), together with an evaporation rate of $1.20 \mathrm{~m}$ and on-lake precipitation rate of $0.18 \mathrm{~m}$, were used in the reconstruction.

Table 1

Correlation statistics for annual discharges of rivers that head in the Sierra Nevada (Fig. 8). Correlations have been made between individual rivers and the Yuba River. Discharge data were taken from rivers having upstream sites with minimal diversion. Truckee River discharges at the Farad site were corrected for reservoir storage and evaporation; discharges from Tahoe City were subtracted from the corrected discharges. The coefficient of determination $\left(R^{2}\right)$ and residual mean square of the correlation between the Yuba and uncorrected Truckee River discharges are 0.60 and 0.54

\begin{tabular}{lll}
\hline River pair & $\begin{array}{l}\text { Coefficient of } \\
\text { determination }\end{array}$ & $\begin{array}{l}\text { Residual } \\
\text { mean square }\end{array}$ \\
\hline $\begin{array}{l}\text { Western flank of Sierra Nevada } \\
\text { Yuba: Yuba }\end{array}$ & 1.00 & 0.00 \\
Yuba: American & 0.91 & 0.13 \\
Yuba: Stanislaus & 0.91 & 0.11 \\
Yuba: Tuolomne & 0.86 & 0.21 \\
Yuba: Merced & 0.86 & 0.21 \\
Yuba: Kern & 0.67 & 0.49 \\
Eastern flank of Sierra Nevada & & \\
Yuba: Truckee & 0.87 & 0.18 \\
Yuba: Carson & 0.91 & 0.09 \\
Yuba: Walker & 0.87 & 0.13 \\
\hline
\end{tabular}




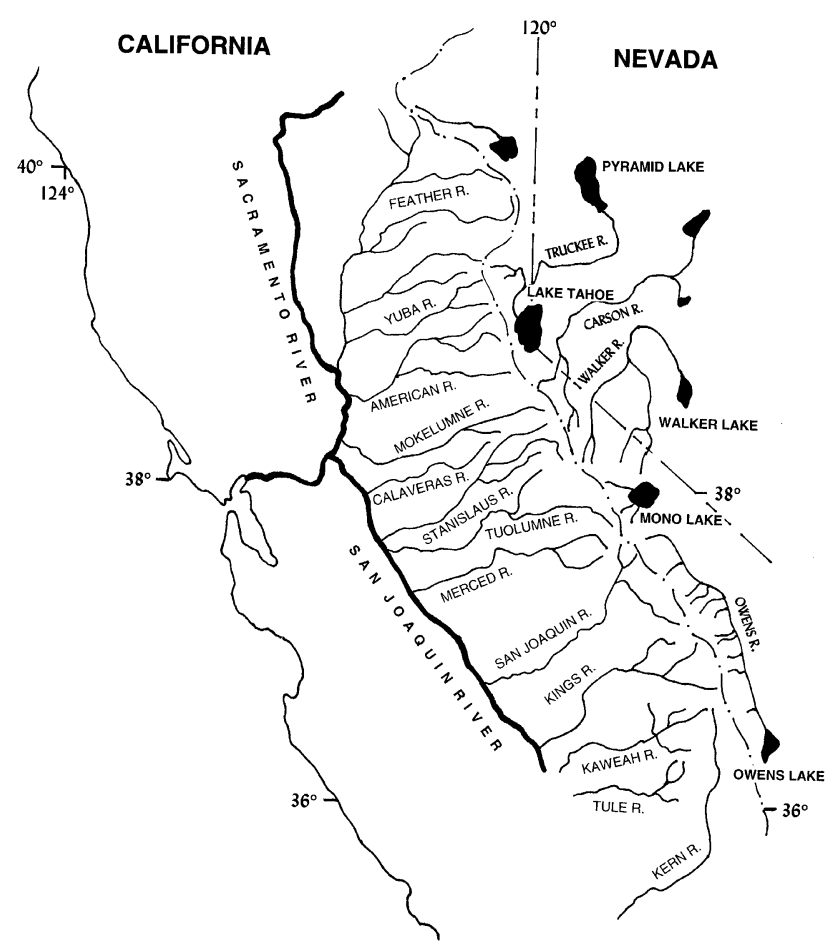

Fig. 8. Surface drainage of streams emanating from the Sierra Nevada, California and Nevada. Streams flowing east terminate in Great Basin lakes and sinks; streams flowing west become part of either the Sacramento or San Joaquin River systems which terminate in San Francisco Bay, California. The crest of the Sierra Nevada is shown as a dashed-dotted line. In the spring and early summer, winter snows, which accumulate along the Sierran crest, melt, feeding rivers located on both flanks of the Sierras.

Three processes comprise the hydrologic balance of Pyramid Lake: Truckee River discharge, evaporation, and on-lake precipitation. Annual values of evaporation $\left(\right.$ mean $\left.=1.21 \mathrm{~m} \mathrm{yr}^{-1}\right)$ do not exhibit much variability in the Pyramid Lake area $(\sigma=0.11 \mathrm{~m}$, Table 2$)$ because the evaporation season is characterized by a near absence of cloud cover. The variability of on-lake precipitation, in absolute terms, is even smaller $(\sigma=0.07 \mathrm{~m}$, Table 2). When compared to discharge variability $(\sigma=0.55 \mathrm{~m})$, evaporation and precipitation variability contribute only $\sim 15 \%$ and $\sim 10 \%$ of the total variance, demonstrating why fluctuations in the size of Pyramid Lake strongly reflect river discharge. Thus a record of change in the volume of Pyramid Lake should be useful in estimating changes in wetness that affect regions located on both sides of the Sierra Nevada.

\subsection{Pyramid Lake is the deepest lake in the Great Basin and sediments accumulate at a rapid rate}

Today (January 2001), Pyramid Lake has a depth of $109 \mathrm{~m}$ and it would be $14 \mathrm{~m}$ deeper if it were not for irrigation demands. Most Great Basin lakes are shallower than Pyramid Lake (Table 3), making them

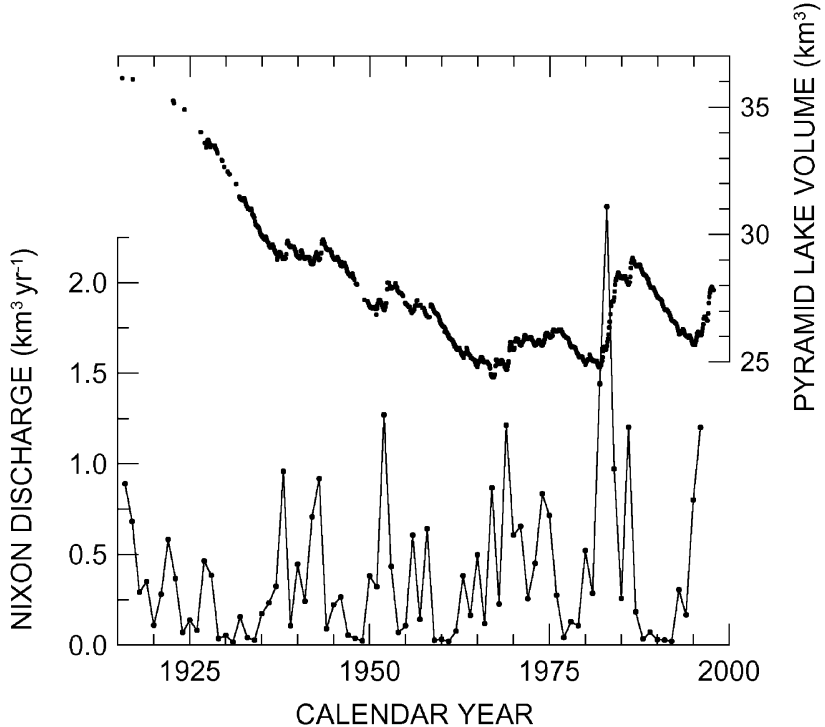

Fig. 9. Comparison of the volume of Pyramid Lake (mostly monthly values) with annual values of discharge of the Truckee River measured at the Nixon, Nevada, gage (Fig. 5). Note that increases in discharge result in abrupt decreases in the volume of Pyramid Lake.

\section{Table 2}

Hydrologic-balance statistics for Pyramid Lake, Nevada. Pyramid Lake evaporation was calculated using measured or estimated values of discharge at Nixon, measured values of precipitation, and the measured surface areas of Pyramid Lake at the beginning and end of the water year. Evaporation from a class-A pan from a site $50 \mathrm{~km}$ east of Pyramid Lake (Fallon, Nevada) is given to better assess evaporation variability. On-lake precipitation was estimated using measured data from Nixon, Sutcliffe, Wadsworth, and Reno, Nevada. Truckee River discharge for the Nixon site was estimated for the period 1916-1957 from correlations of annual discharge between the Nixon gage and a gage located below the Derby Dam (Fig. 5) for the period 1958-1996 (US Geological Survey, 1960, 1961-1997, 1963). The coefficient of determination $\left(R^{2}\right)$ of the correlation is 0.998 and the residual mean square is 0.00066 . The depth of discharge to Pyramid Lake was determined by dividing its the mean annual value of uncorrected discharge at the Farad gage $\left(0.70 \mathrm{~km}^{3}\right)$ by the surface area at the overflow elevation $\left(680 \mathrm{~km}^{2}\right)$

\begin{tabular}{lll}
\hline Parameter & $\begin{array}{l}\text { Period of } \\
\text { record }\end{array}$ & $\begin{array}{l}\text { Statistics } \\
\left(\mathrm{m} \mathrm{yr}^{-1}\right)\end{array}$ \\
\hline Pyramid Lake evaporation & $1932-1966$ & $1.21 \pm 0.11$ \\
Pan evaporation (Fallon, Nevada) & $1957-1992$ & $0.89 \pm 0.08$ \\
On-lake precipitation & $1900-1997$ & $0.18 \pm 0.07$ \\
Truckee River discharge & $1916-1996$ & $1.04 \pm 0.55$ \\
\hline
\end{tabular}

more susceptible to desiccation and deflation during severe drought. Because of their shallow nature, many of these lakes experience reworking of material from shallow- to deep-water sites.

In order to resolve changes in the hydrologic balance at a sub-decadal scale, sediments must accumulate rapidly. As discussed in a later section of this paper, the sedimentation rate of deep-water Pyramid Lake sediments has ranged from $\sim 0.12$ to $\sim 0.23 \mathrm{~cm} \mathrm{yr}^{-1}$ 
Table 3

Depths (historical ranges) of some lakes in the Great Basin. The deepest values generally indicate depths measured on or about 1900 before substantial river diversions occurred

\begin{tabular}{ll}
\hline Lake & Depth $(\mathrm{m})$ \\
\hline Pyramid Lake & $99-123$ \\
Walker Lake & $30-75$ \\
Mono Lake & $37-51$ \\
Winnemucca Lake & $0-26$ \\
Great Salt Lake & $6-13$ \\
Owens Lake & $0-7$ \\
Abert Lake & $0-6$ \\
Ruby Lake & $0-5$ \\
Summer Lake & $0-2$ \\
\hline
\end{tabular}

during the past $7630 \mathrm{calyr}$, permitting a sampling integration of $1-8 \mathrm{yr}$.

\section{Coring and age control}

To obtain a multi-millennial record of drought frequency for the northern Sierra Nevada and bordering regions, a 5.35-m piston core (PLC97-1) was taken from the deep basin of Pyramid Lake in 1997 (Fig. 10). Because sediments in the trigger core (PCL97-1 T) were disturbed during shipping, a 0.59-m box core (PLB98-2) was taken from the deepest part $(107 \mathrm{~m})$ of Pyramid Lake in 1998. A $6.34 \mathrm{~m}$ piston core (PLC98-4) was also taken from the deep basin in order to recover older Holocene-age sediments. In 1999, surface sediments were sampled at 13 sites located along a transect between the deep basin and the western shore of Pyramid Lake (Fig. 10).

Age control for PLB98-2 was provided using measured profiles of ${ }^{137} \mathrm{Cs}$ and $\mathrm{Hg}$. The onset of measurable ${ }^{137} \mathrm{Cs}$ was used to associate a depth of $16.0 \mathrm{~cm}$ with 1952 $\mathrm{AD}$ (Fig. 11) and the first peak in ${ }^{137} \mathrm{Cs}$ was used to associate a depth of $22.2 \mathrm{~cm}$ with $1964 \mathrm{AD}$. In the same manner, $\mathrm{Hg}$ analyses of digested sediment samples were used to associate a sharp rise in $\mathrm{Hg}$ concentration at $42.5 \mathrm{~cm}$ with $\sim 1860$ AD (Alan Heyvaert, personal communication). Mining in the Comstock/Virginia City area began in $1859 \mathrm{AD}$ and was well underway by 1860 $\mathrm{AD}$ with both smelting and $\mathrm{Hg}$ amalgamation processes established in the Washoe Lake area that drains to the Truckee River (Smith, 1998). Four depth-age associations were used to establish an age model for PLB98-2 sediments (Fig. 12).

Age control for PLC97-1 was established by comparing its paleomagnetic secular variation (PSV) record with a well-dated western United States archeomagnetic record (Lund, 1996). We consider the PLC97-1 age model (Fig. 13) (Table 4) accurate to within 50-100 yr. Modern materials from Pyramid Lake have been found to exhibit a 600-yr reservoir effect (Broecker and

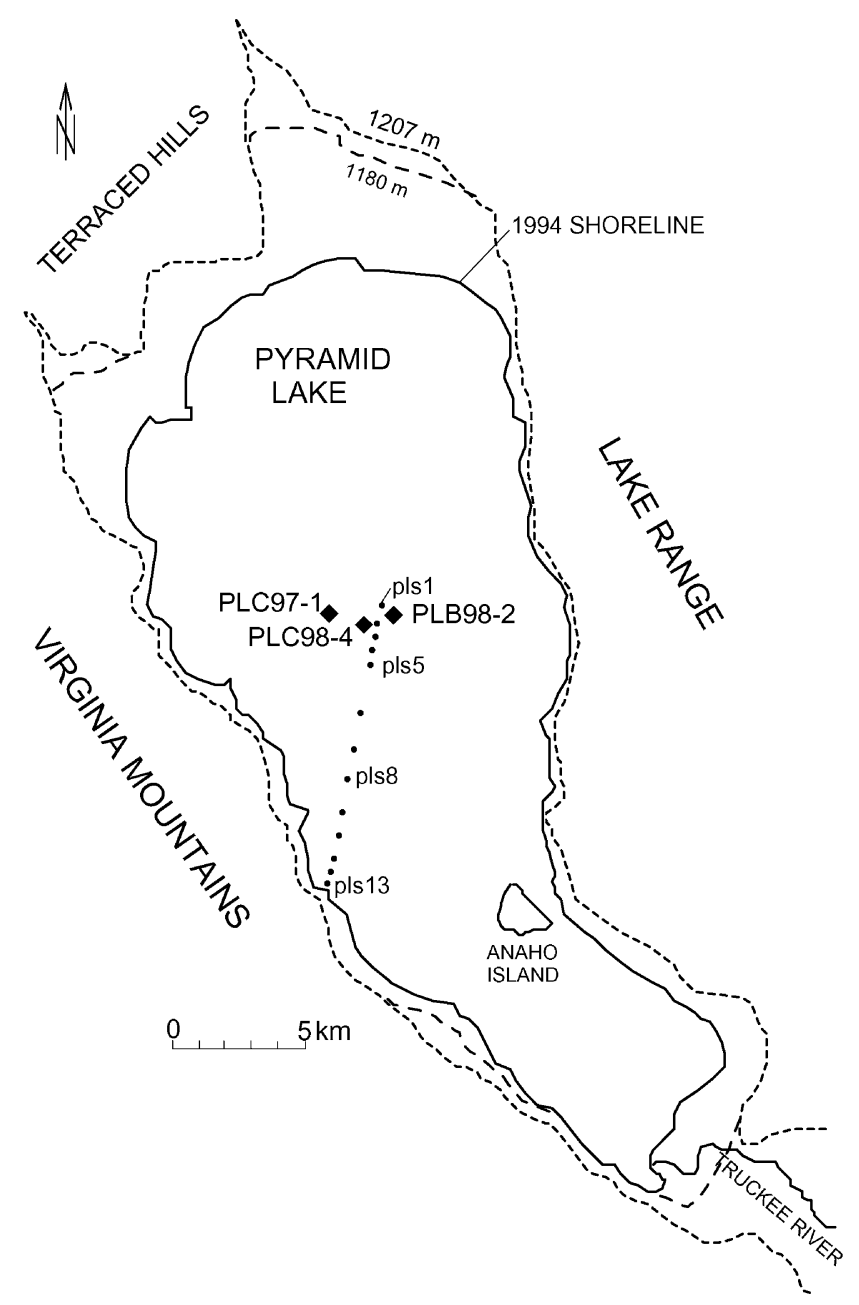

Fig. 10. Coring sites, Pyramid Lake, Nevada. Water depths are $>100 \mathrm{~m}$ at the sites of the piston and box cores (PLC97-1, PLC98-4, PLB98-2). PLS samples are sediment-water interface samples taken along a transect starting in the deep basin of Pyramid Lake and ending at Pelican Point. The inner dashed line indicates the area that Pyramid Lake achieved during overflow to the Winnemucca Lake basin.

Walton, 1959). Radiocarbon ages on the total organic carbon (TOC) fraction of six samples from PLC97-1 were also found to be about $600 \mathrm{yr}$ older than their PSVbased ${ }^{14} \mathrm{C}$ ages (Fig. 14) (Table 5), suggesting that the $600-\mathrm{yr}$ reservoir effect may have persisted throughout the Holocene.

Radiocarbon determinations were performed on the TOC fraction of 30 samples from PLC98-4 (Table 6). The data, plotted as a function of depth, exhibit a great deal of scatter (Fig. 15). We assume that scatter off the line drawn in Fig. 15 indicates reworking and transport of organic carbon from older sediments that border the sides of Pyramid Lake basin. This is consistent with the enhanced reworking of older shoreline sediments to the center of a shallow early middle-Holocene lake (see below). We do not know the value of the reservoir effect in Pyramid Lake during the middle Holocene; therefore, 


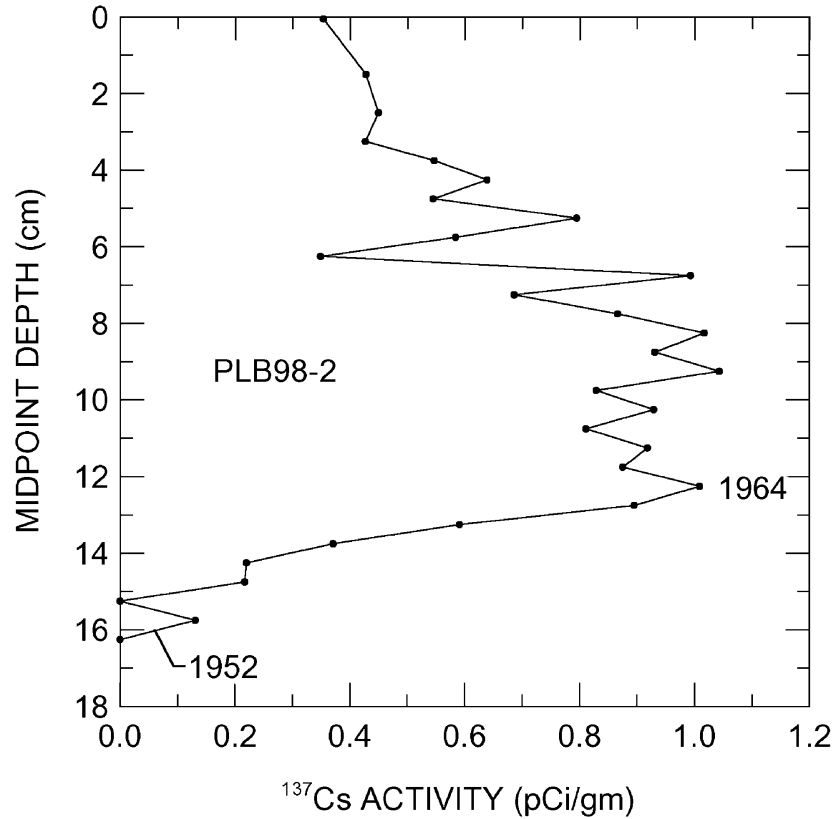

Fig. 11. ${ }^{137} \mathrm{Cs}$ values for boxcore PLB98-2 (data were obtained by Jack Dibb, University of New Hampshire).

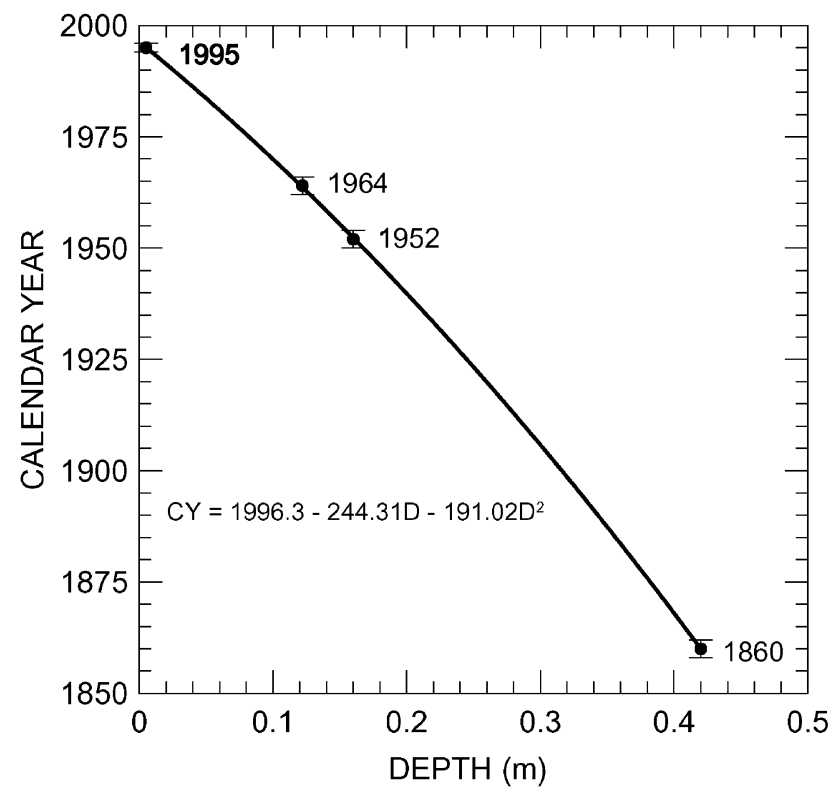

Fig. 12. Calendar-year depth model for PLB98-2.

for the PLC98-4 age model we have assumed it to be identical to the late Holocene value. After subtracting a reservoir value of $600 \mathrm{yr}$ and converting the ${ }^{14} \mathrm{C}$ data to calendar years, we fit a polynomial to four samples that we assume to have suffered the least amount of organic carbon contamination (Fig. 16).

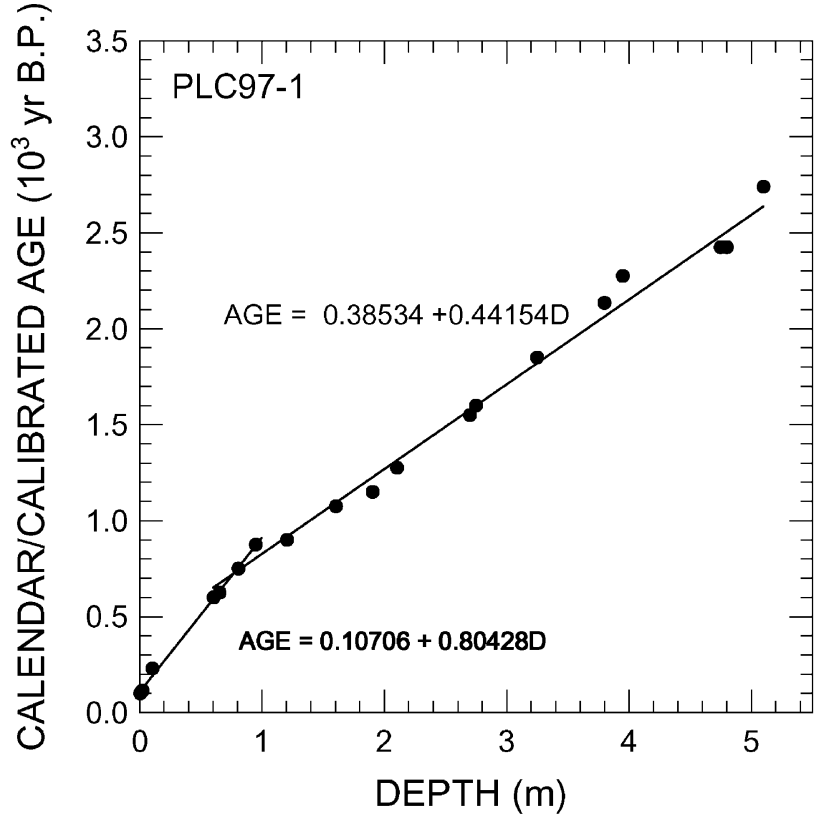

Fig. 13. Calendar-year depth model for PLC97-1. Individual inclination and declination features in paleomagnetic secular variation (PSV) record for PLC97-1 were correlated with similar features from a welldated composite archeomagnetic (ARCMAG) PSV record from the western USA. PSV feature calendar-year ages from the ARCMAG record were assigned to the same features in PLC97-1.

Table 4

PSV-based calendar ages and their ${ }^{14} \mathrm{C}$ age equivalents for PLC97-1. Conversion from calendar to ${ }^{14} \mathrm{C}$ ages done using Table 1 in Stuiver et al. (1998)

\begin{tabular}{llll}
\hline Depth $(\mathrm{m})$ & $\begin{array}{l}\text { PSV age } \\
\left(10^{3} \mathrm{yr} \mathrm{BP}\right)\end{array}$ & $\begin{array}{l}\text { PSV error } \\
\left(10^{3} \mathrm{yr} \mathrm{BP}\right)\end{array}$ & $\begin{array}{l}{ }^{14} \mathrm{C} \text { age } \\
\left(10^{3} \mathrm{BP}\right)\end{array}$ \\
\hline 0.10 & 0.230 & 0.020 & 0.105 \\
0.60 & 0.600 & 0.025 & 0.600 \\
0.65 & 0.625 & 0.025 & 0.613 \\
0.80 & 0.750 & 0.025 & 0.862 \\
0.95 & 0.875 & 0.025 & 0.897 \\
1.20 & 0.900 & 0.025 & 0.933 \\
1.60 & 1.075 & 0.025 & 1.186 \\
1.90 & 1.150 & 0.025 & 1.205 \\
2.10 & 1.275 & 0.050 & 1.324 \\
2.70 & 1.550 & 0.050 & 1.666 \\
2.75 & 1.600 & 0.075 & 1.698 \\
3.25 & 1.850 & 0.050 & 1.888 \\
3.80 & 2.142 & 0.100 & 2.140 \\
3.95 & 2.158 & 0.100 & 2.190 \\
4.80 & 2.426 & 0.125 & 2.400 \\
5.10 & 2.741 & 0.125 & 2.570 \\
\hline
\end{tabular}

\section{Reworking and bioturbation of sediments}

Although the data are few in number, ${ }^{14} \mathrm{C}$ ages of sediments that form the sides of the Pyramid Lake basin 


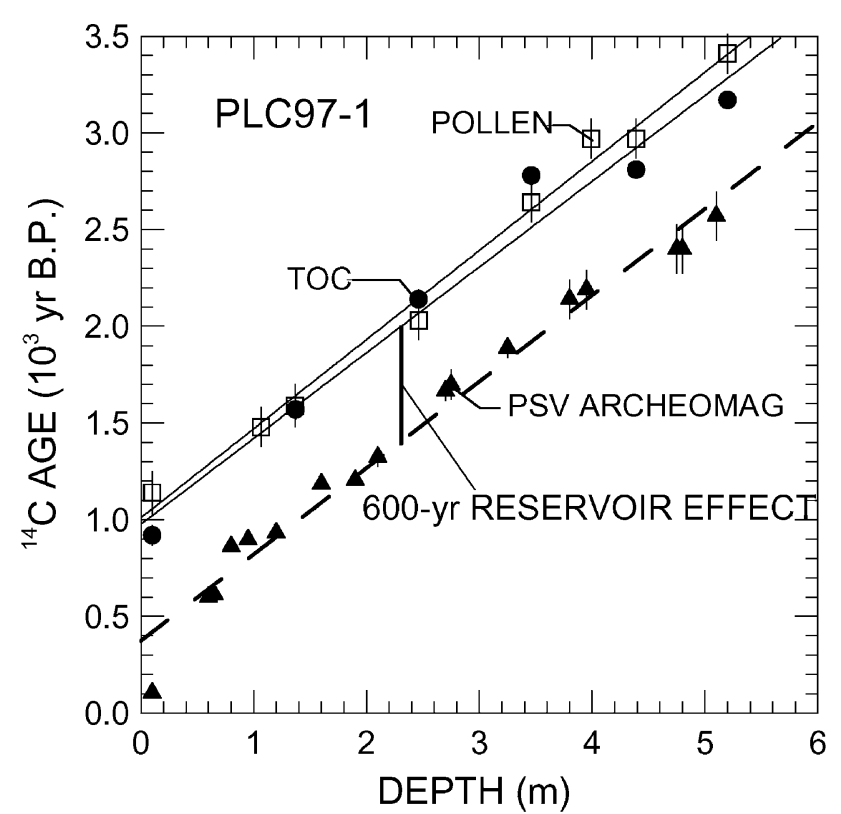

Fig. 14. Radiocarbon ages of TOC samples (solid line), pollen samples (dotted line), and PSV features (dashed line) versus depth in PLC97-1. Calendar ages of PSV features were converted to ${ }^{14} \mathrm{C}$ ages using Table 1 in Stuiver et al. (1998).

Table 5

Radiocarbon ages of TOC and pollen fractions from core PLC97-1. Approximately 10,000 grains of pollen (primarily pine) were extracted from each sample (Mensing and Southon, 1999)

\begin{tabular}{lllll}
\hline Cams \# & Sample type & $\begin{array}{l}\text { Depth } \\
(\mathrm{m})\end{array}$ & $\begin{array}{l}{ }^{14} \mathrm{C} \text { age } \\
\left(10^{3} \mathrm{BP}\right)\end{array}$ & $\begin{array}{l}{ }^{14} \mathrm{C} \text { age error } \\
\left(10^{3} \mathrm{BP}\right)\end{array}$ \\
\hline 38464 & TOC & 0.10 & 0.92 & 0.05 \\
38550 & TOC & 1.37 & 1.57 & 0.05 \\
39750 & TOC & 2.46 & 2.14 & 0.05 \\
39751 & TOC & 3.46 & 2.78 & 0.05 \\
38465 & TOC & 4.39 & 2.81 & 0.04 \\
39817 & TOC & 5.20 & 3.17 & 0.04 \\
& & & & \\
42276 & Pollen & 0.100 & 1.14 & 0.11 \\
42288 & Pollen & 1.065 & 1.48 & 0.10 \\
42279 & Pollen & 1.365 & 1.59 & 0.11 \\
42282 & Pollen & 2.463 & 2.03 & 0.10 \\
42291 & Pollen & 3.460 & 2.64 & 0.10 \\
42294 & Pollen & 3.990 & 2.97 & 0.10 \\
42297 & Pollen & 4.390 & 2.97 & 0.10 \\
42300 & Pollen & 5.200 & 3.41 & 0.10 \\
\hline
\end{tabular}

tend to decrease with depth (Fig. 17). Modern sediments that remain uncontaminated with older materials have not been commonly encountered at elevations above $\sim 1075 \mathrm{~m}$ ( $\sim 20 \mathrm{~m}$ above the base of the deep basin). Erosion and reworking/resuspension of older sediments from the sides of the basin is thus thought responsible for the depth-age distribution of surface sediments. In a
Table 6

Radiocarbon and calendar/calibrated ages for TOC fraction of samples from PLC98-4. A reservoir correction of $600 \mathrm{yr}$ was applied to the ${ }^{14} \mathrm{C}$ date before conversion to calendar years

\begin{tabular}{|c|c|c|c|c|c|}
\hline Cams \# & $\begin{array}{l}\text { Depth } \\
(\mathrm{m})\end{array}$ & $\begin{array}{l}{ }^{14} \mathrm{C} \text { Age } \\
\left(10^{3} \mathrm{BP}\right)\end{array}$ & $\begin{array}{l}{ }^{14} \mathrm{C} \text { age error } \\
\left(10^{3} \mathrm{BP}\right)\end{array}$ & $\begin{array}{l}\text { Calendar age } \\
\text { good samples }\end{array}$ & $\begin{array}{l}\text { Calendar age } \\
\text { best samples }\end{array}$ \\
\hline 55079 & 0.630 & 3.98 & 0.05 & 3.60 & 3.60 \\
\hline 54967 & 0.770 & 4.18 & 0.04 & 3.85 & \\
\hline 54968 & 1.015 & 4.33 & 0.05 & 4.14 & \\
\hline 53001 & 1.070 & 4.39 & 0.04 & 4.16 & \\
\hline 53002 & 1.290 & 4.50 & 0.04 & 4.36 & \\
\hline 53003 & 1.540 & 4.85 & 0.04 & & \\
\hline 53004 & 1.790 & 4.85 & 0.04 & 4.84 & \\
\hline 51321 & 1.940 & 4.90 & 0.04 & 4.86 & \\
\hline 53005 & 1.960 & 4.96 & 0.04 & 4.87 & \\
\hline 51322 & 2.170 & 5.04 & 0.04 & 4.89 & 4.89 \\
\hline 51323 & 2.430 & 5.79 & 0.04 & & \\
\hline 51006 & 2.470 & 5.87 & 0.05 & & \\
\hline 51324 & 2.680 & 5.29 & 0.04 & 5.45 & \\
\hline 54963 & 2.940 & 5.66 & 0.05 & 5.78 & \\
\hline 54964 & 3.190 & 5.77 & 0.06 & 5.92 & \\
\hline 54965 & 3.420 & 5.88 & 0.05 & 6.08 & \\
\hline 54966 & 3.650 & 6.62 & 0.05 & & \\
\hline 53007 & 3.960 & 6.27 & 0.05 & 6.43 & \\
\hline 53008 & 4.210 & 6.54 & 0.05 & & \\
\hline 53009 & 4.530 & 6.29 & 0.04 & 6.48 & 6.48 \\
\hline 53010 & 4.695 & 6.60 & 0.04 & 6.86 & \\
\hline 53011 & 5.025 & 7.23 & 0.05 & & \\
\hline 51319 & 5.245 & 7.19 & 0.04 & & \\
\hline 53012 & 5.275 & 7.45 & 0.04 & & \\
\hline 53013 & 5.475 & 7.78 & 0.04 & & \\
\hline 51320 & 5.495 & 8.19 & 0.04 & & \\
\hline 53014 & 5.715 & 7.27 & 0.05 & & \\
\hline 51360 & 5.755 & 7.27 & 0.04 & 7.57 & \\
\hline 51318 & 6.005 & 7.13 & 0.04 & 7.57 & \\
\hline 51315 & 6.260 & 7.68 & 0.05 & 7.46 & 7.46 \\
\hline
\end{tabular}

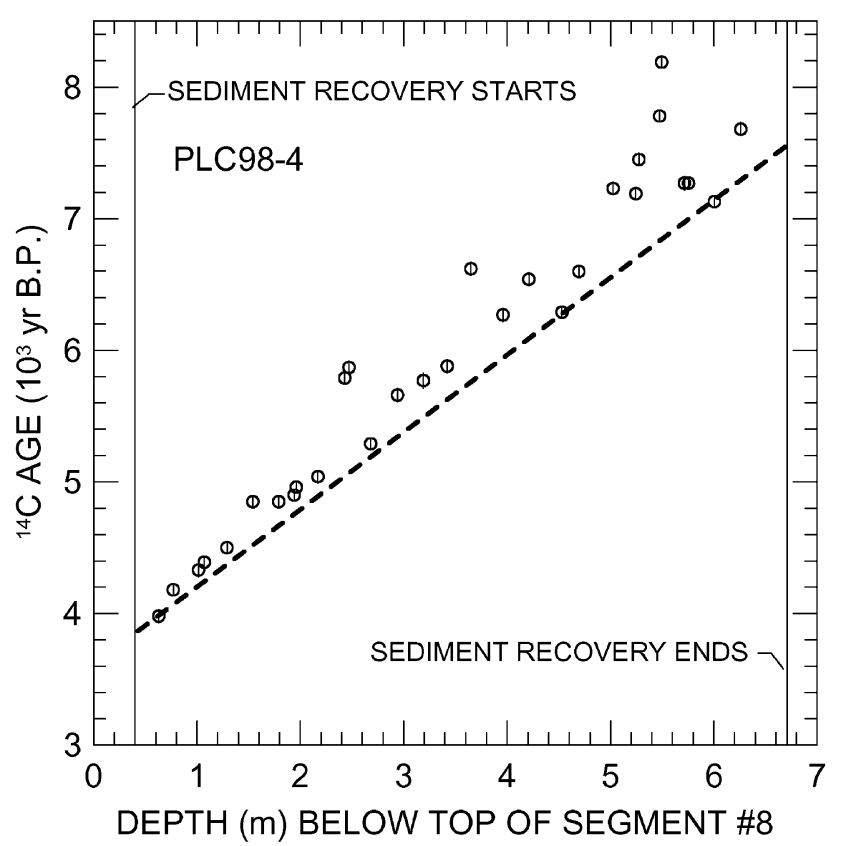

Fig. 15. Radiocarbon ages of the TOC fraction of samples from PLC98-4. The dashed line is assumed to represent samples that are not contaminated by reworked organic carbon. 


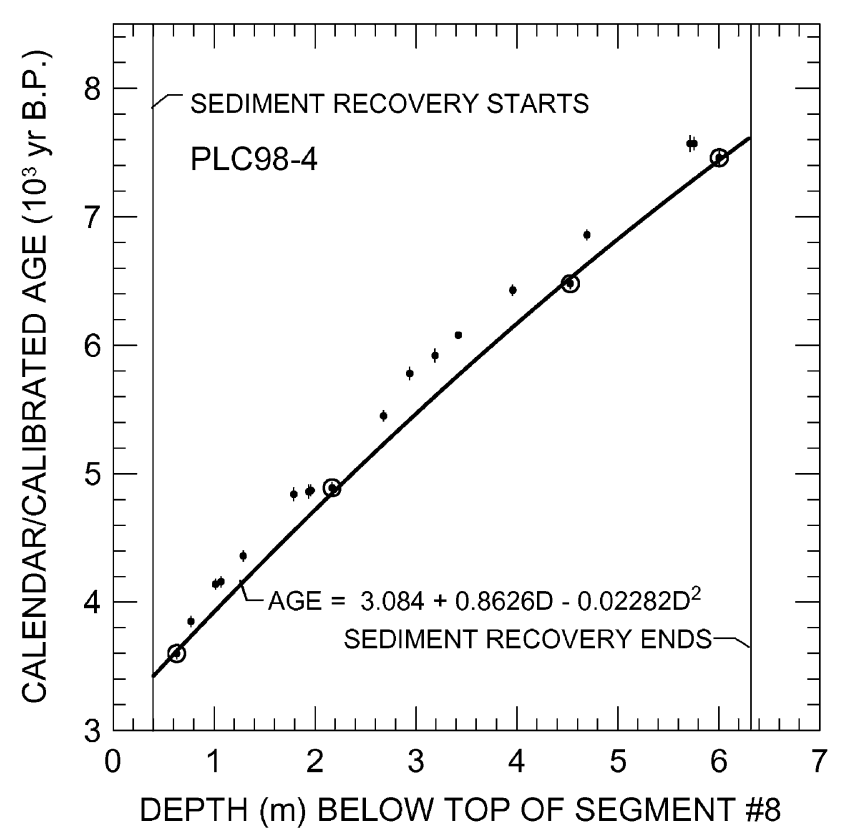

Fig. 16. Calendar-year depth model for PLC98-4 (solid line). A 600-yr reservoir-effect value has been subtracted from the ${ }^{14} \mathrm{C}$ ages prior to conversion to calendar years. The four samples that were least contaminated with organic carbon (indicated by large open circles) were used to construct the age model discussed in the text. Samples with minor amounts of contamination are indicated by small solid dots.

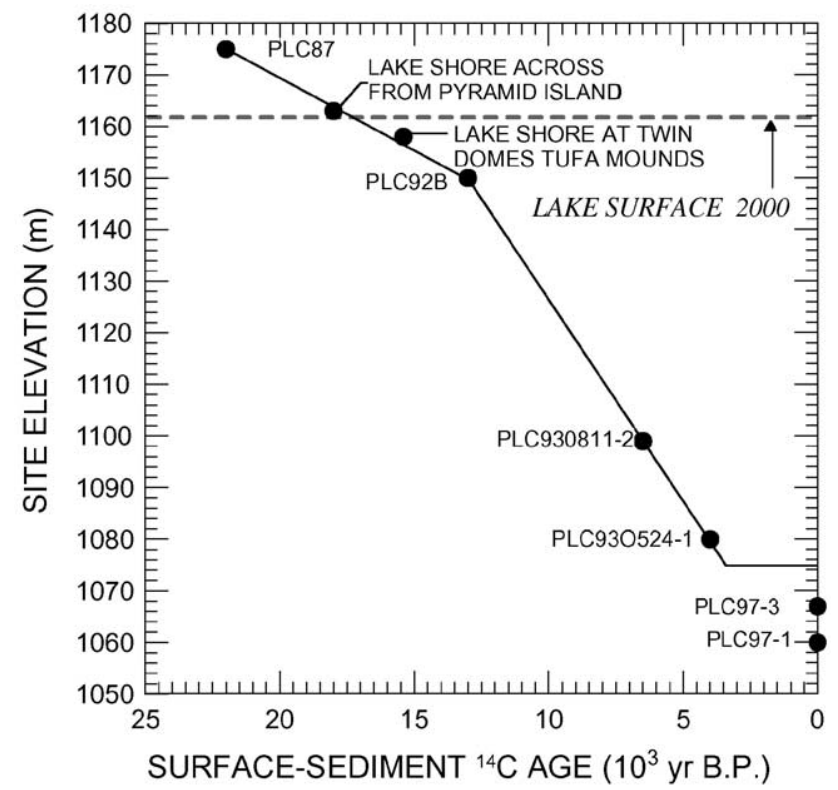

Fig. 17. Radiocarbon ages of sediments forming the surface of the Pyramid Lake basin. The three highest elevation sites were above water at the time of their sampling. These sites, as well as cores PLC930811-2 and PLC930524-1, contained reworked material on top of undisturbed sediments. Radiocarbon ages were determined on the TOC fraction from the top of the undisturbed sediments.

study of Pyramid Lake surface sediments, Lebo et al. (1993) showed that particulate carbon was concentrated in the deepest areas of Pyramid Lake. In addition, Lebo

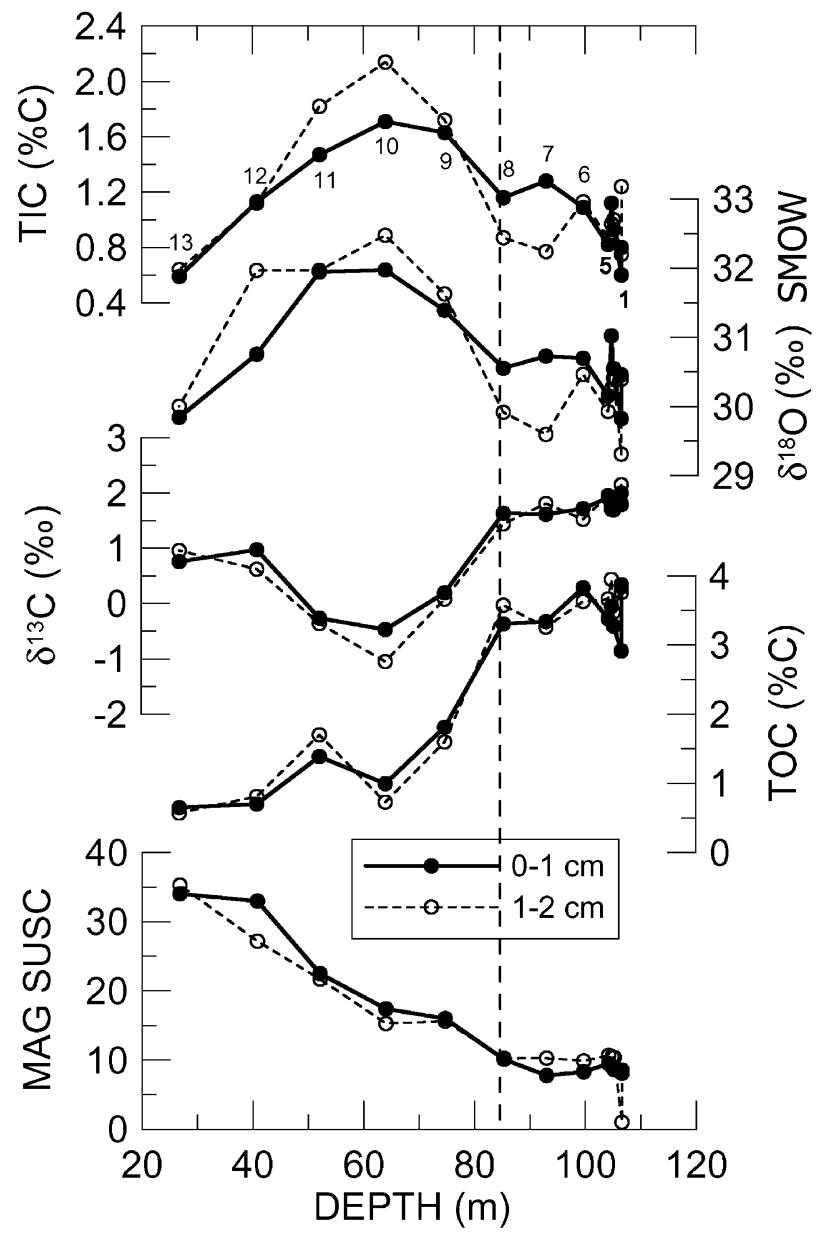

Fig. 18. TOC, $\delta^{13} \mathrm{C}, \delta^{18} \mathrm{O}$, TIC, and magnetic susceptibility data for surface sediment samples taken along the transect depicted in Fig. 10. Numbers refer to locations along the transect. Solid lines indicate data from the top $\mathrm{cm}$ of the samples; dashed lines indicate data from the second $\mathrm{cm}$.

et al. (1993) showed that coarse particles $(>24 \mu \mathrm{m})$ were concentrated in shallow-water areas and fine particles $(<8 \mu \mathrm{m})$ were most abundant in deep waters. We collected surface samples taken along a north-south (deep-shallow) transect (Fig. 10) and found that both the TOC and TIC fractions change with depth (Fig. 18). The TOC percentage is small in water depths $<80 \mathrm{~m}$ but in deeper waters its concentration increases sharply, leveling off at depths $>85 \mathrm{~m}$. We concur with Lebo et al. (1993), that the concentration of particulate carbon and TOC in deep-water sites is due to resuspension and transport of fine sediments during winter/spring storm events.

We found that the TIC percentage reached a maximum at $\sim 65 \mathrm{~m}$ depth (Fig. 18), suggesting that reworking of detrital carbonates, partly derived from tufa deposits that border the lake (Benson, 1994a), does not contribute much material to deep-water sediments. Grain size analyses of samples from 2.0 and $13.5 \mathrm{~cm}$ in 
PLB98-2 indicate that the fine sand and silt fractions in the deep basin were much higher in $1961 \pm$ than in $1992 \pm$, indicating more reworking of coarser material to the deep basin when the lake was shallower (Fig. 6).

Additional evidence for reworking of older material and its transport to deeper water comes from ${ }^{14} \mathrm{C}$ ages of pollen (mainly pine) extracted from PLC97-1. The pollen dates are offset $\sim 650 \pm 50{ }^{14} \mathrm{C}$ yr from the PSV age model (Fig. 14, Table 5), indicating a contribution of older reworked pollen, probably derived from the sides of the lake basin. Assuming that pollen ages are similar to the ages of the sediment from which they were derived (Fig. 17), we can gain some idea of the magnitude of reworking by calculating the amount of "old" pollen that would have to be added to the modern pollen rain to yield the 650 -yr offset. Contributions of $8.5 \%, 9.0 \%$, and $11.0 \%$ of, respectively, $20,000,15,000$, and $10,000{ }^{14} \mathrm{C}$-yr-old reworked pollen to the modern pollen rain would account for the age offset. We conclude, therefore, that $\sim 10 \%$ of the fine-sediment fraction reaching the deep basin of Pyramid Lake during the late Holocene was derived from reworking of older sediments from the sides of the basin.

Smear slides taken from cores PLC97-1 and PLC98-4 provide information about fine-grained sediments at thicknesses of less than a millimeter. Preliminary examination of smear slides indicate a significant component of shallow-water attached diatoms (Gomphonema, sp., Acanthes sp., and Amphora sp.) (Galat et al., 1981) within all sediment, indicating transport of sediment away from shoreline areas. The fraction of attached diatoms increases in layers with higher detrital grain content, particularly in the lower part of PLC98-4. Near the base of PLC98-4, layers of muddy sand that grade to sandy mud suggest intermittent turbidite deposition. This association is consistent with the existence of a small shallow lake in which coarse sediment is being transported to the core site.

The only layering in most of PLC97-1 and the lower part of the trigger core (PLC97-1 T) consists of 5-20 cm thick bands of sediment which are either light or dark in color. The light-colored layers are richer in carbonate than the dark layers. The absence of finer laminations is probably due to disturbance by burrowing organisms. Sinuous, cylindrical, sediment-filled features lined with dark sulfides are interpreted as burrows (Smoot and Benson, 1998). The cylinders have diameters ranging from 1 to $8 \mathrm{~mm}$. The length of any cylinder rarely exceeds $3 \mathrm{~cm}$, but sediment from an overlying layer has been found in cylinders as much as $8 \mathrm{~cm}$ below its source.

In the upper, water-rich parts of cores, contacts between layers are very diffuse. X-radiographs indicate that the contacts are riddled with horizontally and vertically oriented cylindrical features, suggesting that the diffuse contacts result from bioturbation. Presum- ably, any internal stratification within a band experienced a similar scale of mixing. Lower in the core, where the sediment has undergone compaction, the contacts are sharper and the layers are easily distinguishable. Compaction, accompanying water loss, has squeezed the bioturbated layers. As a consequence, mostly vertically oriented burrows remain visible. The net effect of the bioturbation is not complete homogenization but a smoothing of sediment properties over thickness, ranging from one to several centimeters.

\section{Methods}

The top $20 \mathrm{~cm}$ of the 59-cm box core (PLB98-2) was sampled every $0.5 \mathrm{~cm}$. The bottom $39 \mathrm{~cm}$ of the box core and the entire length of the piston cores (PLC97-1 and PLC98-4) were sampled every cm, except for segment \#4 from PLC98-4 which was sampled every $2 \mathrm{~cm}$ between 2.78 and $3.76 \mathrm{~m}$. Samples from PLB98-2 integrated 1.0 to $7.4 \mathrm{yr}$; samples from PLC97-1 integrated 4.4 to $8.0 \mathrm{yr}$, and samples from PLC98-4 integrated from 5.7 to $8.4 \mathrm{yr}$, except samples from segment $\# 4$ which integrated from 10.5 to $14.7 \mathrm{yr}$. Prior to TIC and $\delta^{18} \mathrm{O}$ analyses, each sample was combined with deionized water, shaken and centrifuged for $15 \mathrm{~min}$ at $20,000 \mathrm{rpm}$ using a Sorval Superspeed RC2B. ${ }^{1}$ After centrifugation, the conductivity of the supernatant was measured and the supernatant discarded. This procedure was repeated until the conductivity of the supernatant was $<3$ times the conductivity of Boulder, Colorado, tap water. The sample was then freeze dried and homogenized with a mortar and pestle. Isotopic analyses $\left(\delta^{18} \mathrm{O}\right.$ and $\left.\delta^{13} \mathrm{C}\right)$ were made on the TIC fraction using a Kiel device connected to a Finnigan MAT 251 mass spectrometer. The $\sigma$ value of $\delta^{18} \mathrm{O}$ measurement (16 analyses of the same sample made at different times) was $0.22 \%$. When a $\delta^{18} \mathrm{O}$ analysis differed by $\geqslant 0.2 \%$ from adjacent analyses, the sample was rerun. When it was noted that $\delta^{18} \mathrm{O}$ values for PLC98-4 were, on average, distinctly lower than values for PLC97-1, a procedure was instigated whereby two samples from PLC97-1 were incorporated into each set of PLC98-4 analyses. The average difference $(0.34 \%)$ between the PLC97-1 $\delta^{18} \mathrm{O}$ values obtained in 1997 and 1998 was then subtracted from the PLC98-4 data sets.

TIC and total carbon (TC) were run using a UIC Model 5012 carbon dioxide coulometer. TOC was determined by difference. X-ray diffraction scans between $25^{\circ}$ and $30^{\circ} 2 \theta$ were done using a Siemens Kristalloflex $805(\mathrm{CuK} \alpha$ radiation) on samples taken from about every $25 \mathrm{~cm}$ in core PLC97-1 and from about every $50 \mathrm{~cm}$ in PLC98-4. $\mathrm{Hg}$ analyses were done

\footnotetext{
${ }^{1}$ Use of trade, product, or company name within this paper does not constitute an endorsement by the US Government.
} 
on three samples from the upper $24 \mathrm{~cm}$ of PLC97-1 by cold-vapor atomic fluorescence spectrometry. $\mathrm{The} \mathrm{Hg}$ detection limit was $0.4 \mathrm{ng} \mathrm{Hg} \mathrm{g}^{-1}$. Radiocarbon determinations were made at the Center for Applied Mass Spectrometry at the Lawrence Livermore National Laboratory.

Long-core magnetic susceptibility measurements (2$\mathrm{cm}$ interval) were made of all piston and trigger cores the same day they were collected. Several weeks to months later, the cores were split and paleomagnetic samples cubes $(2 \times 2 \times 2 \mathrm{~cm})$ were recovered every $2.5 \mathrm{~cm}$ from piston core PLC97-1. The natural remanent magnetizations (NRM) and magnetic susceptibilities of all samples were measured and selected samples were demagnetized at $10,20,30,40,60$, and $80 \mathrm{mT}$ alternating-magnetic field. A weak viscous overprint was routinely removed before $20 \mathrm{mT}$ demagnetization in all samples and the remaining NRMs demagnetized simply toward the origin. A paleomagnetic record of field variability was estimated for PLC97-1 using the NRMs of all samples demagnetized at $20 \mathrm{mT}$. The declinations were rotated by their average value so that the average core declination was $0^{\circ}$. The final paleomagnetic results were then compared with other welldated paleomagnetic records from the western United States (Lund, 1996; unpublished data) and selected paleomagnetic inclination and declination features were correlated to them. Surface sediments (PLS series), which had been previously freeze dried, were placed in sample cubes and their sediment weights determined. Magnetic susceptibility measurements were made and normalized to sediment weight in order to facilitate comparison.

\section{Overlap of cores PLB98-2 and PLC97-1}

In order to derive consistent age models for PLB98-2 and PLC97-1, their TC, $\delta^{13} \mathrm{C}$ and $\delta^{18} \mathrm{O}$ profiles were examined. Two choices were evident: the top of PLC971 could be placed at either 18 or $42 \mathrm{~cm}$ below the top of PLB98-2 (Fig. 19). On the basis of the shapes of the TC and $\delta^{18} \mathrm{O}$ profiles, the $42-\mathrm{cm}$ placement was preferred. In order to test this choice, three samples from 3.5, 15.5, and $23.5 \mathrm{~cm}$ below the top of PLC97-1 were freeze dried, digested in a solution of aqua regia and HF acid, and analyzed for $\mathrm{Hg}$. The analyses yielded 11,12 , and $3 \mathrm{ng}$ $\mathrm{Hg} \mathrm{g}^{-1}$ for the samples. The low values of $\mathrm{Hg}$ confirmed the placement of the top of PLC97-1 at $42 \mathrm{~cm}$ in PLB982. Placement higher in PLB98-2 would demand values of $\mathrm{Hg}$ approaching $1.0 \mu \mathrm{g} \mathrm{g}^{-1}$; sediments deposited in the higher interval should have occurred when $\mathrm{Hg}$-amalgamated gold was being retorted in the Virginia City area (see coring and age control section). The age of the top of PLC97-1 was determined from its correlation with
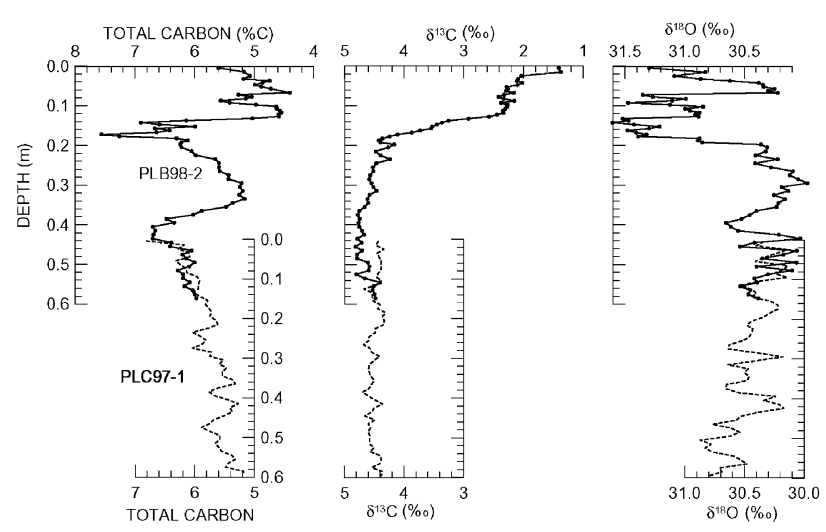

Fig. 19. Plot of TOC, $\delta^{13} \mathrm{C}$ and $\delta^{18} \mathrm{O}$ data from PLB98-2 (solid lines) and the top of PLC97-1 (dashed lines) indicating overlap of cores.

PLB98-2. This date was then used in the PLC97-1 age model (Fig. 13).

\section{Hydrologic indicators}

\section{1. $\delta^{18} \mathrm{O}$}

For a closed-basin lake at hydrologic steady state, $\delta^{18} \mathrm{O}_{\text {lake }}=\delta^{18} \mathrm{O}_{\text {in }}-{ }^{18} \alpha_{\mathrm{H}_{2} \mathrm{O}(\mathrm{l})-\mathrm{H}_{2} \mathrm{O}(\mathrm{v})}$,

where $\delta^{18} \mathrm{O}_{\text {lake }}$ is the steady-state $\delta^{18} \mathrm{O}$ value of lake water, $\delta^{18} \mathrm{O}_{\text {in }}$ is the volume-weighted $\delta^{18} \mathrm{O}$ value of discharge and on-lake precipitation, and ${ }^{18} \alpha_{\mathrm{H}_{2} \mathrm{O}(1)-\mathrm{H}_{2} \mathrm{O}(\mathrm{v})}$, is the fractionation factor between the lake surface and water vapor. For the historical Truckee River-Pyramid Lake system, the $\delta^{18} \mathrm{O}$ values of discharge and on-lake precipitation average $\sim-11 \%$ o and the fractionation factor is $\sim-13 \%$ (Benson, 1994b); ground-water inputs are small. Therefore, at hydrologic and isotopic steady states, $\delta^{18} \mathrm{O}_{\text {lake }}=\sim 2 \%$.

The value of $\delta^{18} \mathrm{O}_{\text {in }}$ has not remained constant with time. There are two principal sources of $\delta^{18} \mathrm{O}_{\text {in }}$ to Pyramid Lake: Sierran snowmelt and Lake Tahoe overflow. The $\delta^{18} \mathrm{O}$ value of Sierran snow is a function of condensation air temperature. Dansgaard (1964) has shown that, on a global basis, $\delta^{18} \mathrm{O}$ in precipitation is related to ground-level air temperature by $\sim 0.7 \%{ }^{\circ} \mathrm{C}^{-1}$. During the past $70 \mathrm{yr}$, average winter air temperatures in the Lake Tahoe area have increased by $\sim 2^{\circ} \mathrm{C}$ (Western Regional Climate Center historical summaries, http:// www.wrcc.dri.edu/). Such changes on longer time scales occurred during the past 8000 calyr (see discussion below), causing variability in the $\delta^{18} \mathrm{O}$ value of Sierran snows.

Water in Lake Tahoe has a long residence time ( $235 \mathrm{yr}$ ). Evaporation from Lake Tahoe has resulted in a $\delta^{18} \mathrm{O}$ value $(-5.6 \%)$ much larger than that of snowmelt $(-14.6 \%)$. Thus, during droughts when Lake 
Tahoe ceases spilling, the $\delta^{18} \mathrm{O}$ value of Truckee River discharge decreases from $\sim-11 \%$ to $\sim-14.6 \%$. The input of $-14.6 \%$ water to Pyramid lake causes its $\delta^{18} \mathrm{O}$ value to first increase as its volume decreases; however, its steady-state value $(-1.6 \%)$ is much smaller than when the lake receives spill from Lake Tahoe.

Another factor affecting the $\delta^{18} \mathrm{O}$ record is the temperature of $\mathrm{CaCO}_{3}$ precipitation. For every $1{ }^{\circ} \mathrm{C}$ increase in water temperature there is a corresponding $0.21 \%$ decrease in the $\delta^{18} \mathrm{O}$ value of precipitated aragonite (O'Neil et al., 1969).

The fractionation factor between lake water and water vapor $\left({ }^{18} \alpha_{\mathrm{H}_{2} \mathrm{O}(\mathrm{l})-\mathrm{H}_{2} \mathrm{O}(\mathrm{v})}\right)$, is a complicated function of air temperature, water temperature, humidity over the lake, wind speed, and the $\delta^{18} \mathrm{O}$ value and humidity of advected air that passes over the lake (Benson and White, 1994). During the warm season when evaporation rates are high, a closed-basin desert lake may be assumed to create its own local climate; i.e., it generates the humidity and $\delta^{18} \mathrm{O}$ values in the air mass overlying the lake surface. Under such conditions, variability in the fractionation factor is mostly due to changes in water temperature and amounts to $\sim 0.1 \%{ }^{\circ} \mathrm{C}^{-1}$ (Benson and White, 1994).

In what follows, we tend to stress the response of $\delta^{18} \mathrm{O}$ to abrupt changes in the hydrologic balance of Pyramid Lake. However, this is not the only process governing the value of $\delta^{18} \mathrm{O}_{\text {lake }}$; therefore, we will also present calculations that seek to elucidate the effects of temperature variability on the value of $\delta^{18} \mathrm{O}_{\text {in }}$ and on the fractionation factor between $\delta^{18} \mathrm{O}_{\text {lake }}$ and the aragonite that precipitates from lake water.

Because climate changes on all time scales, hydrologic and isotopic steady states are never fully achieved. During a wet period, input of isotopically light river water exceeds loss of isotopically-light evaporated water. As the volume of a closed-basin lake increases, $\delta^{18} \mathrm{O}_{\text {lake }}$ decreases; the faster the volume increase, the greater the decrease in $\delta^{18} \mathrm{O}_{\text {lake }}$. During a dry period, $\delta^{18} \mathrm{O}_{\text {lake }}$ increases as the lake shrinks, reflecting the dominance of evaporation on the hydrologic and isotopic balances. When a lake overflows, the $\delta^{18} \mathrm{O}$ value of the overflowing lake water, at hydrologic steady state, is proportional to the ratio of the spill $\left(V_{\text {spill }}\right)$ rate relative to lake volume $\left(V_{\text {lake }}\right)$. This is because the residence time of water in the spilling lake decreases with increased rate of spill, lessening the effect of evaporation on the ${ }^{18} \mathrm{O} /{ }^{16} \mathrm{O}$ ratio of the spilling lake. The relationship between $\delta^{18} \mathrm{O}$ and lake volume cannot, therefore, be expressed as an equation of state; i.e., a simple constant relationship between lake volume and $\delta^{18} \mathrm{O}_{\text {lake }}$ does not exist. For example, input of a unit volume of isotopically depleted river water will cause a greater negative shift in $\delta^{18} \mathrm{O}_{\text {lake }}$ when lake volumes are small rather than when lake volumes are large.
In the Pyramid Lake basin, four processes can reduce the amplitude of the recorded oscillations in $\delta^{18} \mathrm{O}$. When Pyramid Lake overflows, part of the $\delta^{18} \mathrm{O}$-depleted Truckee River discharge may flow directly into the Winnemucca Lake basin instead of first mixing in the epilimnion of Pyramid Lake. This will reduce the magnitude of the decrease in $\delta^{18} \mathrm{O}$ that occurs during wet periods. In addition, natural driftwood rafts, common along the Truckee during spring high-flow periods, may in the past have blocked the Truckee River, diverting part of its flow to Winnemucca Lake (De Quille, 1889). During dry periods, when Pyramid Lake is small, sediment focusing of older isotopically depleted carbonates from shallow-water high-energy environments into deep-water sites may shift sediment $\delta^{18} \mathrm{O}$ to more negative values. Also, bioturbation of sediment can smooth the $\delta^{18} \mathrm{O}$ record. All four processes blunt the effectiveness of $\delta^{18} \mathrm{O}$ as an indicator of the absolute intensities of dry and wet periods but they do not detract from its usefulness in determining durations of climatic oscillations.

\section{2. $T I C$}

X-ray diffraction indicates that the TIC fraction is predominantly composed of aragonite. TIC is a somewhat "fuzzy" indicator of lake-size changes; however, TIC has been shown to reflect the transition from closed to open conditions and can be useful in assessing abrupt changes in the hydrologic balance of a lake (Benson et al., 1996a,1997). Dissolved $\mathrm{Ca}^{2+}$ input to Pyramid Lake via the Truckee River has a short residence time within the lake, precipitating as aragonite $\left(\mathrm{CaCO}_{3}\right)$. The concentration of $\mathrm{Ca}^{2+}$ in the Truckee River is relatively constant at all but its lowest discharges (Fig. 20), indicating that the mass of $\mathrm{Ca}^{2+}$ input to Pyramid Lake is a linear function of discharge. However, the mass of siliciclastic material (suspended load) input to Pyramid Lake by the Truckee River is most likely an exponential function of discharge. Thus, the fraction of TIC deposited in Pyramid Lake sediments should decrease with increasing discharge (increasing lake size). When Pyramid Lake overflows, a further reduction in the fraction of TIC occurs because of the lowered residence time of water in the Pyramid Lake basin. This is because the saturation state of the lake (with respect to $\mathrm{CaCO}_{3}$ ) decreases in proportion to the $V_{\text {spill }}: V_{\text {lake }}$ ratio, but clastics transported to Pyramid Lake will be trapped within the lake basin.

The simple conceptual model of a decrease in TIC with increasing wetness will not generally apply if the distance between a core site and its sediment source varies greatly over time. During a persistent lowstand, greater amounts of clastic sediment carried by the Truckee River will reach the Pyramid Lake deep-water site, diluting the carbonate component. Persistent 


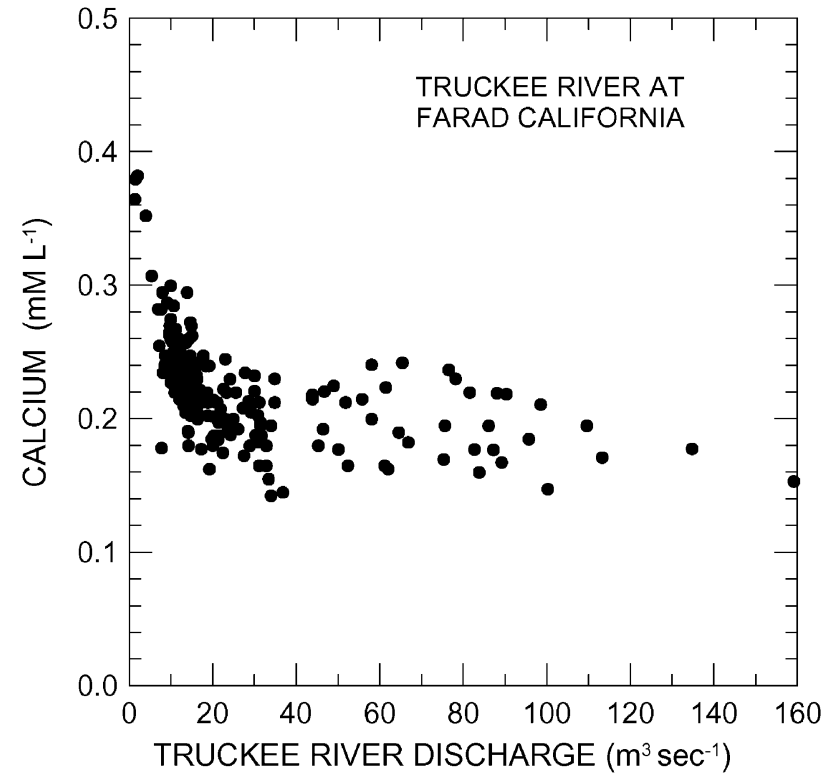

Fig. 20. Dissolved $\mathrm{Ca}^{2+}$ in the Truckee River plotted as function of mean daily discharge at the Farad, California, gage (Fig. 5). Note that except for the lowest discharge rates, the concentration of $\mathrm{Ca}^{2+}$ remains constant.

decreases in lake size will also lead to reworking and transport of old (12,000-20,000 yr), TIC-poor $(<0.7 \%)$, basin-edge sediment to the deep-water site. We do, however, expect TIC to parallel abrupt changes in $\delta^{18} \mathrm{O}$ brought about by rapid changes in lake size because these changes occur at an "instant" in time and are unaffected by persistent long-term changes in lake size. During such instantaneous changes, the distance between sediment sources and the deep-water site remain essentially the same.

\subsection{Magnetic susceptibility}

Magnetic susceptibility of surface sediment samples decreases almost linearly with depth in Pyramid Lake, leveling off at about $85 \mathrm{~m}$ (Fig. 18). Visual observation of the surface sediment indicates that most coarsegrained sediment is trapped in shallow water $(<70 \mathrm{~m}$ water depth) deposits and that only the finest-grained silts and clays reach the deep basin. We assume that most of the magnetic susceptibility resides in ferromagnetic magnetite (the detrital magnetic mineral carrying the NRM). Magnetic susceptibility of magnetite is quite insensitive to changes in grain size, so that the diminished susceptibility values in the deep basin must be due to changes in detrital sediment composition with increasing depth. Most magnetite, being denser than average sediment, is preferentially retained in shallowwater environments, whereas relatively non-magnetic clays are preferentially focused into deep-water sites. When lake-size decreases, distance between the shore and the deep basin decreases and a greater proportion of magnetite-rich sediment reaches the deep basin.

\section{Numerical simulations of the effects of changes in hydrologic balance on Pyramid Lake $\delta^{18} \mathrm{O}$}

In order to assess the response of Pyramid Lake $\delta^{18} \mathrm{O}$ to changes in climate, a hydrologic-balance isotope model was created. Variable inputs to the model consist of the following: initial depth and $\delta^{18} \mathrm{O}$ of Pyramid Lake, annual Truckee River discharge volumes, the $\delta^{18} \mathrm{O}$ values and annual amounts of precipitation received by Pyramid Lake, annual rates of evaporation from Pyramid Lake, the $\delta^{18} \mathrm{O}$ value of runoff (snowmelt) in the Truckee River watershed, and the $\delta^{18} \mathrm{O}$ value of Lake Tahoe. Fixed inputs necessary for calculation of the fractionation of ${ }^{18} \mathrm{O}$ during evaporation include monthly values of relative humidity, air temperature, water temperature, and the $\delta^{18} \mathrm{O}$ value and fraction of advected air in the boundary layer over Pyramid Lake (Benson and White, 1994). Measured values of wind speed were used to set the value of the isotopic kinetic fractionation factor used in the isotope model.

When Lake Tahoe was allowed to spill in model runs, the $\delta^{18} \mathrm{O}$ value of Truckee River discharge was calculated by combining one part Lake Tahoe water (having a $\delta^{18} \mathrm{O}$ of $-5.5 \%$ ) with two parts of snowmelt runoff (having a $\delta^{18} \mathrm{O}$ of $-14.5 \%$ ). When Lake Tahoe ceased overflowing, a $\delta^{18} \mathrm{O}$ of $-14.5 \%$ was used for Truckee River discharge. The $\delta^{18} \mathrm{O}$ value of monthly onlake precipitation was set to $-10.0 \%$ and the initial $\delta^{18} \mathrm{O}$ value of Pyramid Lake water was set to $0.0 \%$ The model was run with a monthly time step; mean monthly values of the input data were distributed over the annual cycle using historic data sets as guides. The depth of the epilimnion was changed every month, consistent with measured historical values. Mass and isotopic balances were made over the fully mixed volume of the epilimnion each month, and the lake was completely mixed in January of each year.

After the inputs are read, the program (Benson and Paillet, 2002) performs the following sequence of calculations: For the first month,

1. Initial lake volume and surface area are calculated from the initial depth.

2. Kinetic and equilibrium fractionation factors are read in or computed.

3. Discharge and on-lake precipitation are added to the lake.

4. Volume-weighted $\delta^{18} \mathrm{O}$ values of discharge and precipitation are combined with the volume-weighted $\delta^{18} \mathrm{O}$ value of the mixed layer. 
5. The new volume is compared with the overflow volume. If the new volume is greater than the overflow volume, the excess volume is subtracted.

6. Evaporation is subtracted from the lake.

7. The volume-weighted $\delta^{18} \mathrm{O}$ value of the vapor phase is calculated and then subtracted from the volumeweighted $\delta^{18} \mathrm{O}$ value of the mixed layer.

8. The base of the mixed layer is moved to the next month's depth, and if the base penetrates the hypolimnion volume, the volume-weighted $\delta^{18} \mathrm{O}$ value of the entrained hypolimnion volume is mixed with the volume-weighted $\delta^{18} \mathrm{O}$ value of the mixed layer.

Output consists of a listing of input variable values, lake depth and lake volume and 10th-month $\delta^{18} \mathrm{O}_{\text {lake }}$ and $\delta^{18} \mathrm{O}_{\text {Arag }}$ values.

The ability of the model to simulate the hydrologic balance was tested using mean-annual historic (since 1916) values of Truckee River discharge measured at the Nixon, Nevada, gage (Fig. 5), a mean evaporation rate of $1.20 \mathrm{~m} \mathrm{yr}^{-1}$, and a mean-annual on-lake precipitation rate of $0.18 \mathrm{~m} \mathrm{yr}^{-1}$. The results of the simulation compared very well with the measured data, capturing all measured changes in lake volume (Fig. 21).

Several simulations were done to illustrate the effect of hydrologic closure and overflow of Pyramid Lake on its $\delta^{18} \mathrm{O}$ value (Fig. 22) and the effect of hydrologic closure and overflow of Lake Tahoe on Pyramid Lake $\delta^{18} \mathrm{O}$ (Fig. 23). In the numerical simulations, the $\delta^{18} \mathrm{O}$ response to a step-function change in

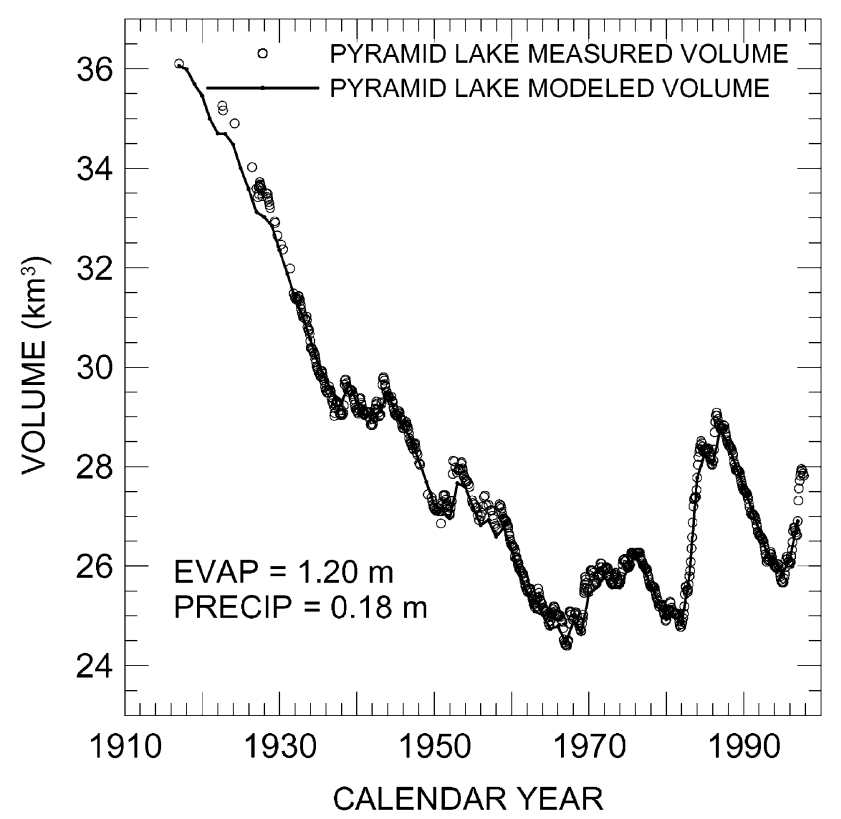

Fig. 21. Comparison of modeled Pyramid Lake volume since 1916 (solid line) and measured values (solid points). This model was used in the calculation of pristine Pyramid Lake elevations (Fig. 7). hydrologic balance consists of an initial transient lasting $<100 \mathrm{yr}$ followed by an exponential $(200-300 \mathrm{yr})$ approach to the steady state. The magnitude, shape, and duration of the transient is proportional to the magnitude and direction of the perturbation imposed on the hydrologic system.

Simulations of the response of Pyramid Lake $\delta^{18} \mathrm{O}$ to overflow into the Winnemucca Lake basin indicate that increasing discharge to Pyramid Lake (and increasing overflow to the Winnemucca Lake basin) results in decreasing values of $\delta^{18} \mathrm{O}$ when hydrologic and isotopic steady states are achieved (Fig. 22). For these simulations, initial lake depth was set to $100 \mathrm{~m}$ and the initial $\delta^{18} \mathrm{O}$ of lake water was set to $0.0 \%$. Use of the historical mean-annual discharge of $0.70 \mathrm{~km}^{3} \mathrm{yr}^{-1}$ (and on-lake precipitation of $\left.0.20 \mathrm{~m} \mathrm{yr}^{-1}\right)$ results in a steady-state $\delta^{18} \mathrm{O}$ value of $-0.1 \%$ (red solid line, Fig. 22). A $15 \%$ increase in Truckee River discharge $\left(0.80 \mathrm{~km}^{3} \mathrm{yr}^{-1}\right)$ shifts the $\delta^{18} \mathrm{O}$ value of lake water an additional $-0.9 \%$ (blue solid line, Fig. 22). Pyramid Lake ceases to spill when total input $\left(V_{\text {in }}\right)$ of water is $\leqslant 0.58 \mathrm{~km}^{3} \mathrm{yr}^{-1}$. Model runs using discharges of 0.30 and $0.40 \mathrm{~km}^{3} \mathrm{yr}^{-1}$ (dotted black and blue lines, Fig. 22) result in the same steady-state $\delta^{18} \mathrm{O}$ value $(2.2 \%)$, but the smaller the discharge the greater the amplitude of the transient response.

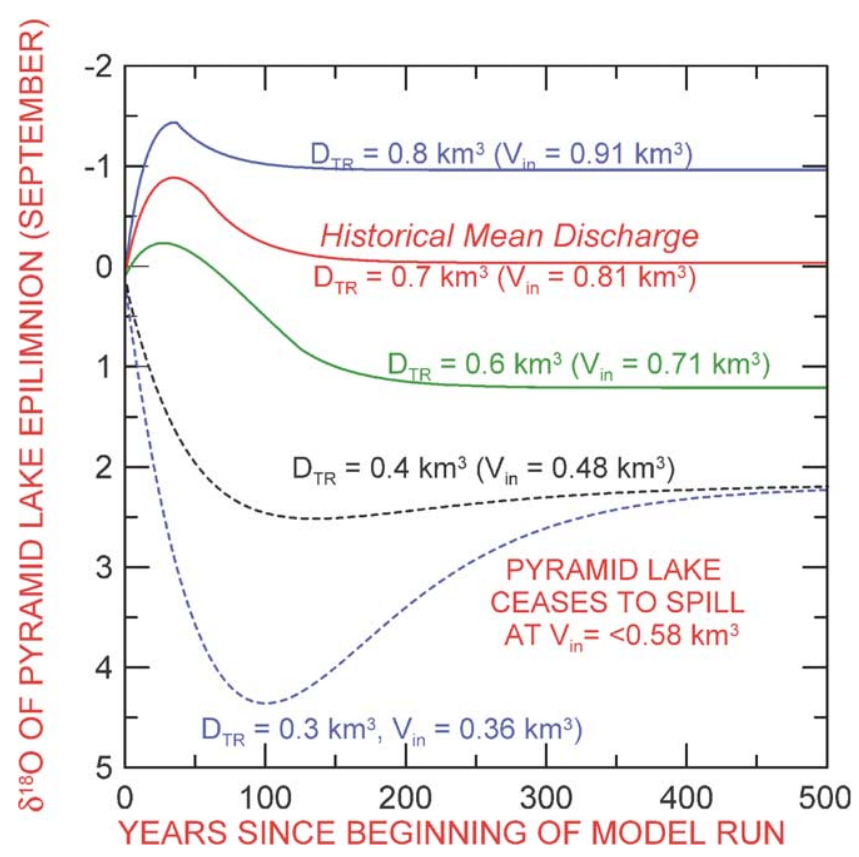

Fig. 22. Simulated $\delta^{18} \mathrm{O}$ values for Pyramid Lake as a function of variable Truckee River discharge $\left(D_{\mathrm{TR}}\right)$. The historical mean discharge of the Truckee River (measured at the Farad gage) is $0.70 \mathrm{~km}^{3} \mathrm{yr}^{-1}$. The total input to the lake $\left(V_{\text {in }}\right)$ equals discharge plus surface-area weighted on-lake precipitation. Note that when Pyramid Lake overflows to Winnemucca Lake basin $\left(V_{\text {in }}=0.58 \mathrm{~km}^{3} \mathrm{yr}^{-1}\right)$, increasing discharge results in smaller values of $\delta^{18} \mathrm{O}$. When Pyramid Lake is closed, the steady-state $\delta^{18} \mathrm{O}$ value is always the same, despite the size of the lake. 


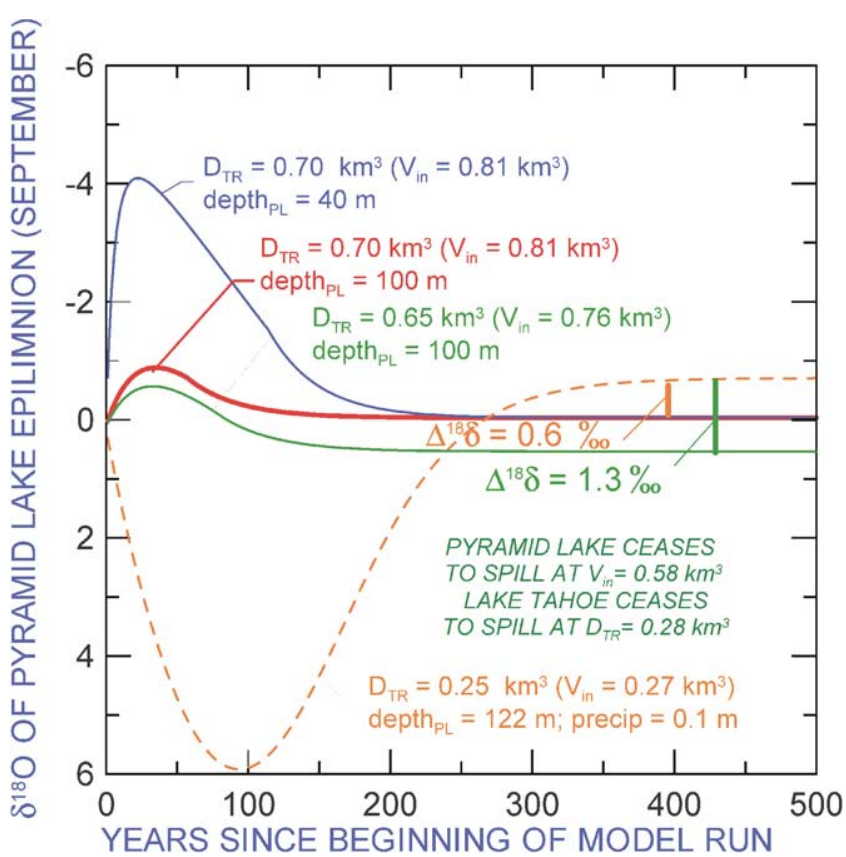

Fig. 23. Simulated responses of Pyramid Lake $\delta^{18} \mathrm{O}$ values to onset of and recovery from severe drought involving hydrologic closure of both Lake Tahoe and Pyramid Lake. Onset of drought sufficient to close Lake Tahoe causes a high-amplitude positive transient response of Pyramid Lake $\delta^{18} \mathrm{O}$ (dashed orange line) followed by an exponential decrease in $\delta^{18} \mathrm{O}$ to a value $0.6 \%$ smaller than that achieved using the pristine mean-historical discharge $\left(0.70 \mathrm{~km}^{3} \mathrm{yr}^{-1}\right)$ (solid blue and red lines). The $\delta^{18} \mathrm{O}$ value resulting from Tahoe closure is $1.3 \%$ less than the value obtained when Truckee River discharge is decreased $7 \%$ relative to its mean historical value (green line). Onset of a wet climate (similar to the historic) after an extended drought which caused Pyramid Lake to fall to a depth of $40 \mathrm{~m}$, results in a high-amplitude negative transient in $\delta^{18} \mathrm{O}$ (solid blue line).

When discharge of the Truckee River is $<0.28 \mathrm{~km}^{3} \mathrm{yr}^{-1}$, both Lake Tahoe and Pyramid Lake exist as hydrologically closed systems. We have simulated the response of Pyramid Lake $\delta^{18} \mathrm{O}$ to a loss of Lake Tahoe overflow, setting Pyramid Lake's initial depth to $122 \mathrm{~m}$ and setting the discharge of the Truckee River to $0.25 \mathrm{~km}^{3} \mathrm{yr}^{-1}$ (dashed orange line, Fig. 23). Under these circumstances, Pyramid Lake first experiences a large positive transient in $\delta^{18} \mathrm{O}$ before attaining a steady-state value of $-0.7 \%$. This represents a negative $0.6 \%$ shift in Pyramid Lake $\delta^{18} \mathrm{O}$ relative to the steadystate value achieved using pristine mean-historical discharge (solid red line, Fig. 23), and it represents a negative $1.3 \%$ shift in $\delta^{18} \mathrm{O}$ relative to the value achieved when discharge of the Truckee River is $0.65 \mathrm{~km}^{3} \mathrm{yr}^{-1}$ (solid green line, Fig. 23). These results demonstrate that a loss of input of isotopically heavy Lake Tahoe water to the Truckee River decreases the $\delta^{18} \mathrm{O}$ value of Pyramid Lake water during a severe and prolonged drought.
In order to determine the response of Pyramid Lake $\delta^{18} \mathrm{O}$ to transition from a prolonged and severe drought to a condition of increased wetness sufficient to cause Lake Tahoe to spill, the depth of Pyramid Lake was set to $40 \mathrm{~m}$ and Truckee River discharge was set to its pristine mean-historical value of $0.70 \mathrm{~km}^{3} \mathrm{yr}^{-1}$. The results of this simulation indicate that Pyramid Lake $\delta^{18} \mathrm{O}$ initially experiences a negative $4.2 \%$ transient before achieving a steady-state $\delta^{18} \mathrm{O}$ value of $0.1 \%$ (blue solid line, Fig. 23).

We can generalize these results in the following manner. In situations in which climate suddenly switches to a drier state, $\delta^{18} \mathrm{O}$ values first increase, reflecting the initial dominance of evaporation over discharge on the hydrologic and isotopic balances. This is true even when the drier climate is characterized by a lighter $\delta^{18} \mathrm{O}$ value of input water. Only at steady state, will the effects of the lighter discharge value be apparent. In situations in which climate switches to a wetter state, $\delta^{18} \mathrm{O}$ values first decrease, reflecting the initial dominance of discharge over evaporation on the hydrologic and isotopic balances. The ultimate steady-state $\delta^{18} \mathrm{O}$ value will reflect whether the lake remains closed or overflows. If it remains closed, it will achieve the same steady-state $\delta^{18} \mathrm{O}$ value no matter the amount of input (all other factors remaining constant). If the lake spills, its $\delta^{18} \mathrm{O}$ value will be proportional to $V_{\text {spill }} / V_{\text {lake }}$.

Because climate tends to change on all time scales, the hydrologic balance will often change before the steadystate $\delta^{18} \mathrm{O}$ value is achieved and often prior to the end of the transient response. This implies that the $\delta^{18} \mathrm{O}$ record in a sediment core represents a collection of the initial phases of transient responses to high- and middlefrequency climate perturbations superimposed on a lowfrequency background of climate change.

\section{Results}

Cores PLC97-1 and PLC98-4 fail to overlap in time; a gap exists in the sediment record between 3430 and 2740 cal yr BP. The records indicate that a $1.6 \%$ shift in the mean value of $\delta^{18} \mathrm{O}$ occurred within the 690-yr gap and that $\delta^{18} \mathrm{O}$ experienced its highest-amplitude oscillations between 7630 and $6600 \mathrm{cal} \mathrm{yr} \mathrm{BP} \mathrm{(Fig.} \mathrm{24).} \mathrm{The}$ magnetic susceptibility and TIC records, however, do not indicate an abrupt shift in values between 3430 and 2740 calyr BP Records of $\delta^{18} \mathrm{O}$, TIC, and magnetic susceptibility from the three Pyramid Lake cores show that $\delta^{18} \mathrm{O}$ reached its largest values and TIC experienced its largest oscillations during the past $95 \mathrm{yr}$ (Fig. 24). In addition, the rise in magnetic susceptibility that occurred during the past $95 \mathrm{yr}$ was the largest of the past millennium. The striking changes in these parameters result from changes in lake size caused by diversion of the Truckee River. In the next section, we 


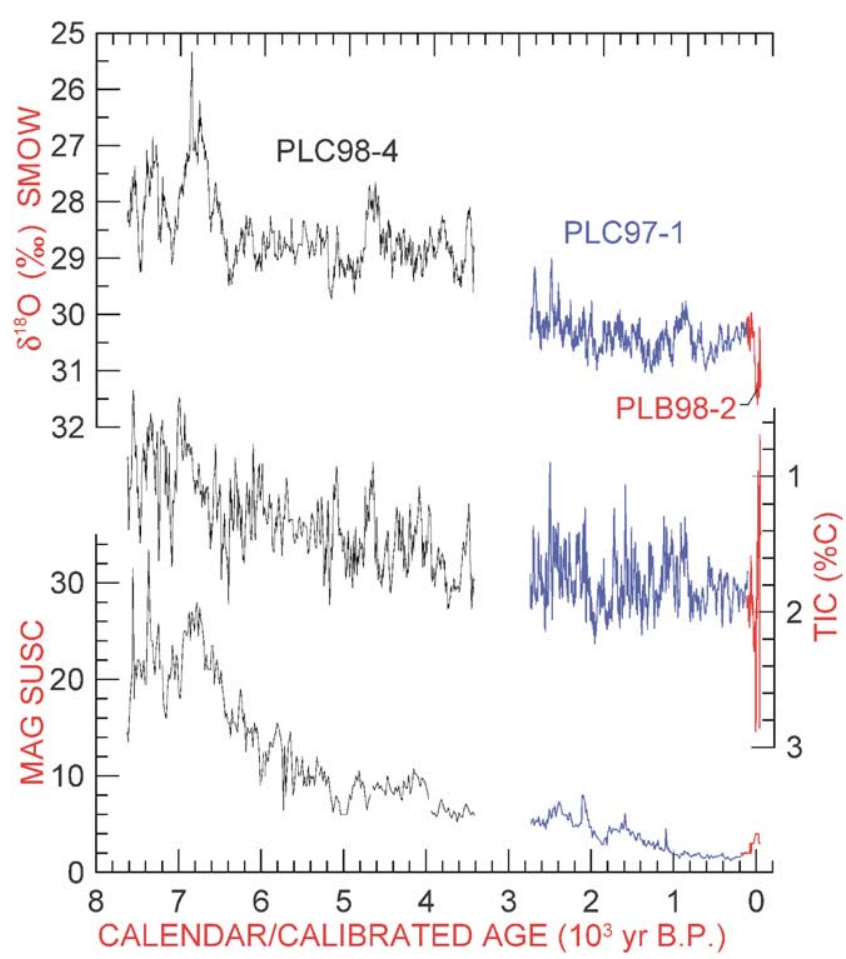

Fig. 24. Magnetic susceptibility, TIC, and $\delta^{18} \mathrm{O}$ records from cores PLB98-2 (122 to -45 cal yr BP, red lines), PLC97-1 (2743111 cal yr BP, blue lines) and PLC98-4 (7640-3430 cal yr BP, black lines).

will discuss the last $100 \mathrm{yr}$ of record, showing that the proxy records of hydrologic change can be related to recorded historical variability in the size of Pyramid Lake.

\subsection{0-2000 AD (core PLB98-2)}

Historical data sets indicate that abrupt changes in TIC and $\delta^{18} \mathrm{O}$ tend to correlate with abrupt changes in lake volume (Fig. 25), demonstrating that $\delta^{18} \mathrm{O}$ and TIC respond similarly to abrupt high-frequency changes in volume. However, the overall trends in TIC and $\delta^{18} \mathrm{O}$ are dissimilar to the overall shape of the lake-volume record, reinforcing the conclusion that neither TIC nor $\delta^{18} \mathrm{O}$ can be related to lake size by an equation of state.

Magnetic susceptibility reached its highest values between $\sim 1940$ and $\sim 1980$ AD when the lake was at low levels, suggesting that larger amounts of magnetiterich siliciclastic sediments from the sides of the basin and/or the delta region were reaching the deep basin. The transport of silicate-rich, carbonate-poor sediments may, in part, explain the decreasing trend in TIC; siliciclastic sediments diluted the TIC fraction when the lake was shallow. Values of $\delta^{13} \mathrm{C}$ decrease over time, reflecting oxidation of isotopically light plant material (sawdust and soil carbon) (Benson et al., 1996b)

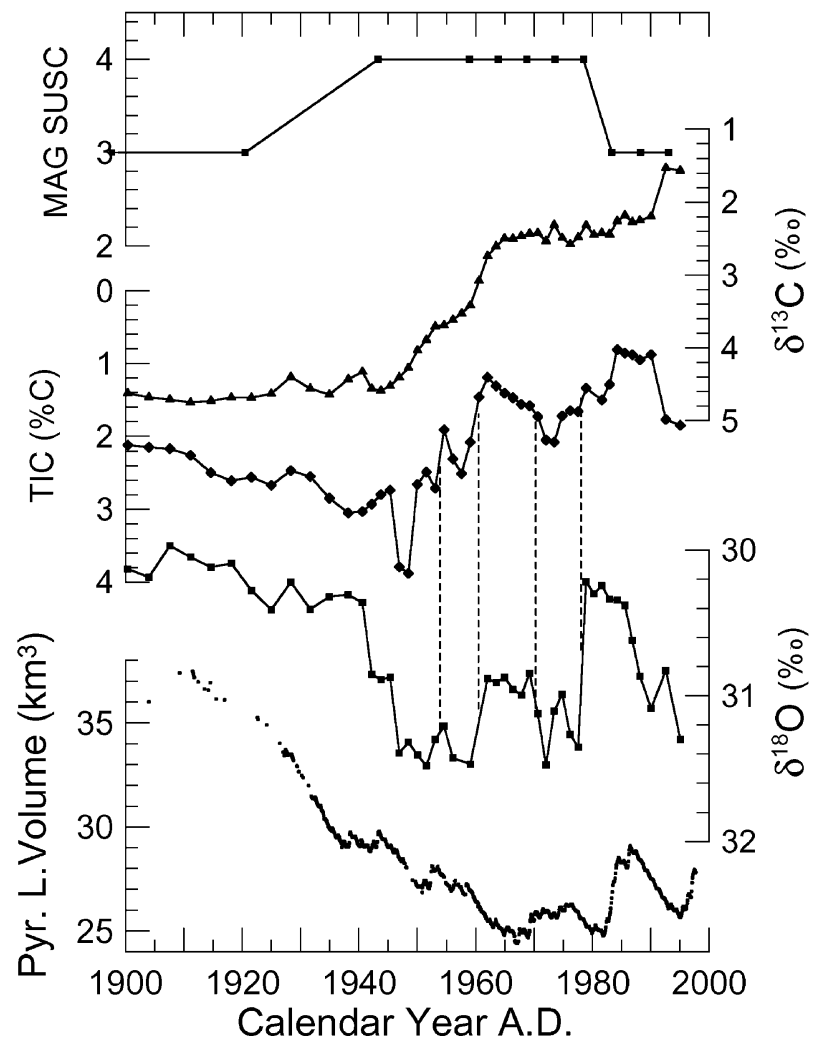

Fig. 25. Magnetic susceptibility, $\delta^{13} \mathrm{C}$, TIC, and $\delta^{18} \mathrm{O}$ records from PLB98-2 plotted against Pyramid Lake volume since 1900. Dashed lines connect nearly simultaneous excursions in the TIC and $\delta^{18} \mathrm{O}$ records associated with abrupt changes in the size of Pyramid Lake.

introduced to the lake during the historical (1863$1930 \pm$ ) deforestation of the Truckee River watershed (Townley, 1980; Wilson, 1992).

\section{2. $2740-110$ cal yr BP}

A cubic spline was fit to the raw $\delta^{18} \mathrm{O}$ and TIC records for PLC97-1; data were extracted every $10 \mathrm{yr}$; and a 40yr running average taken to smooth the data (Fig. 26). A comparison of the smoothed $\delta^{18} \mathrm{O}$ and TIC records indicates that they possess many troughs and peaks in common, indicating their common response to abrupt changes in lake size. The overall shape of the magnetic susceptibility records mirrors the shape of the TIC record between 2740 and $1600 \mathrm{cal} \mathrm{yr} \mathrm{BP}$; increases in magnetic susceptibility parallel decreases in TIC. Be-

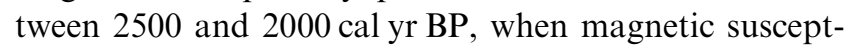
ibility reaches its highest values, peaks in susceptibility often correspond to minima in $\delta^{18} \mathrm{O}$ and TIC. Covariance of the shapes of the $\delta^{18} \mathrm{O}$ and TIC records between 2740 and 1600 cal yr BP suggests dilution of the carbonate fraction with magnetite-bearing siliciclastic sediments. This implies that Pyramid Lake was relatively shallow during this period. The fact that some negative 


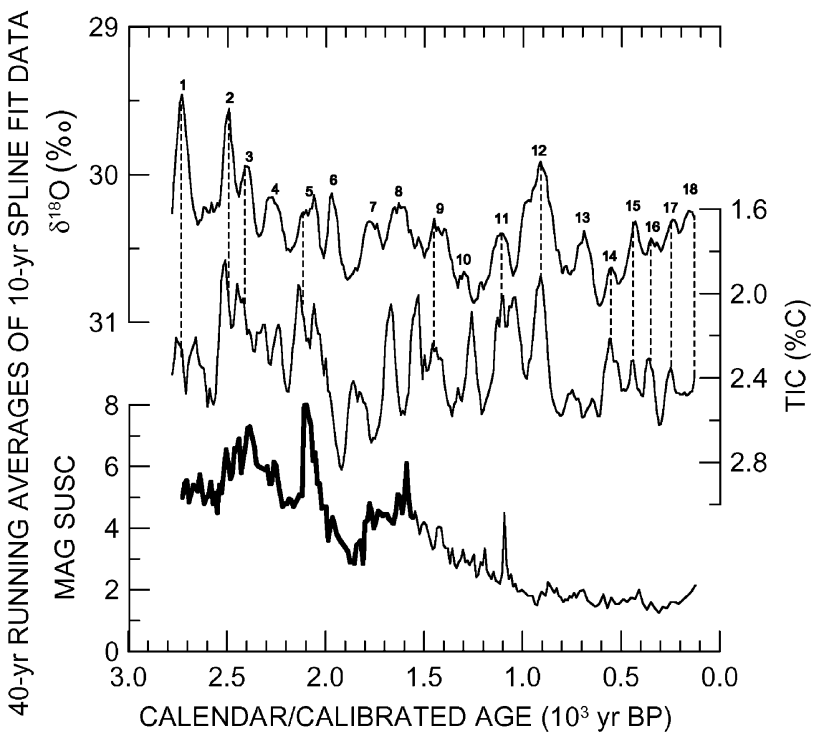

Fig. 26. Smoothed magnetic susceptibility, TIC, and $\delta^{18} \mathrm{O}$ records for PLC97-1. Chemical and magnetic data were smoothed by fitting a cubic spline to data shown in Fig. 24. Data values for all these records were taken at 10-yr intervals from the cubic spline fit and a 4-point (40yr) running average made. Dashed lines indicate times when minima in TIC and $\delta^{18} \mathrm{O}$ coincide. Minima in $\delta^{18} \mathrm{O}$ indicate the termination of a wet period. Wet-dry oscillations have been numbered 1-18.

$\delta^{18} \mathrm{O}$ oscillations occurred at nearly the same times as peaks in magnetic susceptibility suggests that increased wetness may have resulted in greater delivery of magnetite-bearing sediments to Pyramid Lake or that erosion, resuspension, and transport of magnetitebearing materials from shallow-water sediments at the margin of Pyramid Lake to deep water sites occurred during abrupt lake-level rises.

The $\delta^{18} \mathrm{O}$ record between 2740 and $110 \mathrm{BP}$ exhibits oscillations on both decadal and centennial scales (Fig. 24). The smoothing procedure accentuates the existence of 18 oscillations (Figs. 26 and 27a). Noting that the $\delta^{18} \mathrm{O}$ value of aragonite that precipitates from Pyramid Lake is a function of both the $\delta^{18} \mathrm{O}$ value of lake water and the temperature of precipitation, we consider that the oscillations mainly reflect changes in hydrologic balance. If, e.g., the oscillations were solely a function of water temperature, the $1.5 \%$ change in $\delta^{18} \mathrm{O}$ recorded in oscillation \#1 (Fig. 26) would imply a $7^{\circ} \mathrm{C}$ change in temperature, a value we believe to be improbably large.

When drought occurs in the Sierra Nevada, the flow of the Truckee River is reduced and Pyramid Lake falls or the amount of overflow to Winnemucca Lake basin decreases. This results in increasing $\delta^{18} \mathrm{O}$ values of lake water. For the purposes of this paper, we define "hydrologic droughts" as periods during which $\Delta \delta^{18} \mathrm{O} / \Delta t$ tends to be positive; that is, times when lake

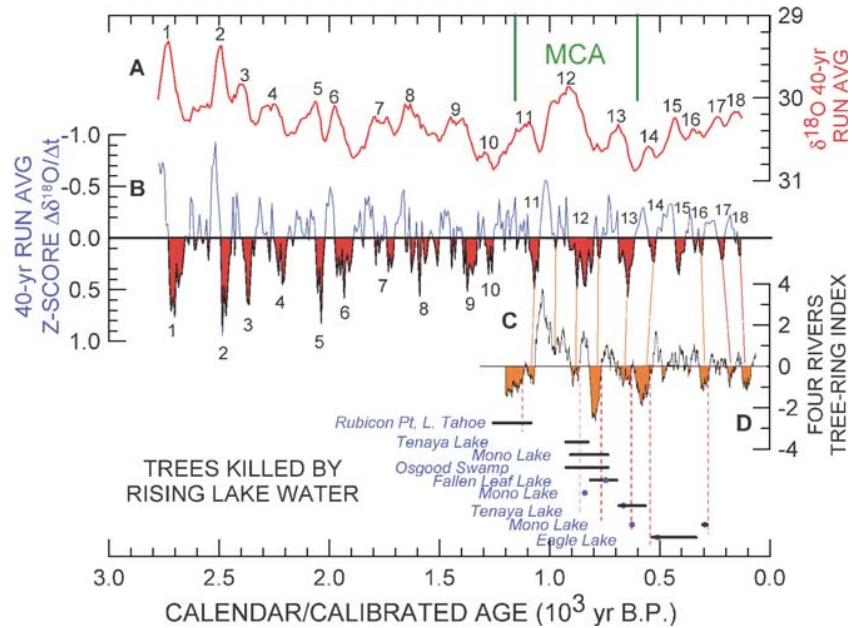

Fig. 27. Comparison of Pyramid Lake $\delta^{18} \mathrm{O}$ record (panel A) and its derivative with respect to time (panel B) with a northern Sierra Nevada tree-ring record (panel $\mathrm{C}$ ) and ages of tree stumps killed by rising lake waters (panel D). (A) 40-yr running average of $\delta^{18} \mathrm{O}$ record from PLC97-1. Oscillations in $\delta^{18} \mathrm{O}$ are numbered 1-18. (B) Smoothed derivative of normalized $\delta^{18} \mathrm{O}$ record shown in panel $\mathrm{A}$; positive values of the derivative, shown as solid areas below the zero line, indicate times when the lake was falling. Hydrologic droughts have been numbered 1 through 18. MCA refers to the time interval occupied by the Medieval Climatic Anomaly (1150-600 cal yr BP). C. Northern Sierra Nevada tree-ring record (Meko et al., 1999); solid areas indicate drought periods. D. Ages of tree stumps killed by rising lake waters (Lawrence and Lawrence, 1961, Stine 1990, 1994). Data for tree stumps at Rubicon Point $\left(1240 \pm 40{ }^{14} \mathrm{C}\right.$ yr BP, Beta 133581) and Fallen Leaf Lake $\left(850 \pm 40{ }^{14} \mathrm{C}\right.$ yr BP, Beta 133580) are part of this study. Solid blue dots indicate best estimates of drought termination. Horizontal black lines reflect uncertainty in the calendar-age estimates of drought termination. Solid orange lines indicate possible correlation between core-based and tree-ring-based drought records. Dashed red lines indicate tree-ring-based timing of drought terminations.

volume (or spill rate) decreases. To determine the timing and duration of droughts, we calculated $\Delta \delta^{18} \mathrm{O} / \Delta t$ using the spline-fit data $(\Delta t=10 \mathrm{yr})$. The derivative record was then normalized ( $Z$-score) and a 40-yr running average taken (Fig. 27b). This procedure demonstrated that droughts occur, on average, once every $150 \mathrm{yr}$; however, the record is not stationary with intervals between droughts ranging from 80 to $230 \mathrm{yr}$. Some droughts persisted for $>100 \mathrm{yr}$, e.g., droughts 1,6 , and 12. During the last $900 \mathrm{yr}$, intervals between droughts appear to have decreased. We stress that the intensities of dry or wet periods cannot be extracted using the derivative-based procedure because the amplitude of the $\delta^{18} \mathrm{O}$ oscillations and their derivatives (Figs. 27a and b) cannot be uniquely related to lake volume.

To test $\Delta \delta^{18} \mathrm{O} / \Delta t$ as an indicator of change in the hydrologic balance, we compared the lake-based drought time series with a tree-ring-based reconstruction of river discharge from the western flank of the northern Sierra Nevada and with ages of stumps of trees that had 
been drowned by rising lakes (Figs. 27c and d). Reconstruction accuracy for the tree-ring series (as measured by $R^{2}$ ) varies from 0.36 for the earliest subperiod model (1250-1084 cal yr BP, 3 sites) to 0.80 for the most recent model $(250-45 \mathrm{cal}$ yr BP, 51 sites) and exceeded 0.60 for all models after $1084 \mathrm{cal}$ yr BP. The correlation between the first two records is reasonably satisfactory with lake-based estimates of most droughts falling within $50 \mathrm{yr}$ of the tree-ring-based estimates. Although the ${ }^{14} \mathrm{C}$-to-cal yr conversion of the ages of the tree stumps yields fairly large age estimates, the stump data are in general agreement with the tree-ring record indicating drought terminations at $\sim 1120, \sim 860$, $\sim 760, \sim 640, \sim 540$, and $\sim 280 \mathrm{cal} \mathrm{yr}$ BP. Drought terminations in the tree-ring record are also apparent at $\sim 460$ and $\sim 360$ cal yr BP.

In the west, the period between 1150 and $600 \mathrm{cal} \mathrm{yr} \mathrm{BP}$ was generally warm, but neither consistently warm nor consistently dry (Hughes and Diaz, 1994). In the Sierra Nevada and White Mountains of California, this period, which has been termed the "Medieval Climatic Anomaly" (MCA), was found to contain two intervals of intense drought separated by an intervening wet interval (Leavitt, 1994; Stine, 1994). In the Pyramid Lake record, the MCA interval is punctuated by three droughts separated by two wet periods (Fig. 27a). The two youngest droughts (\#12 and \#13) are equivalent to the intense droughts identified by Stine (1994). The very low value of $\delta^{18} \mathrm{O}$ achieved at 920 cal yr BP probably resulted from a substantial input of isotopically light water to a lake that had shrunk during drought \#13.

We next addressed the issue of the spatial scales of droughts documented in the tree-ring and lakebased studies by comparing the northern Sierra Nevada tree-ring record with tree-ring reconstructions of precipitation from the southern Sierra Nevada (Graumlich, 1993) and the El Malpais region of northwest New Mexico (Grissino-Mayer, 1996). The $1200-\mathrm{yr}$ tree-ring records indicate that droughts centered at $\sim 800, \sim 660, \sim 490$, and $\sim 360$ cal yr BP impacted all three sites to a some degree (Fig. 28). The 800 and $660 \mathrm{yr}$ BP droughts have also been documented in the Great Basin of southern Nevada (Hughes and Funkhouser, 1998). These two droughts are of general interest because they are associated with sharp reductions in Anasazi population at Chaco Canyon, New Mexico, at 820 cal yr BP (Cordell and Gumerman, 1989) and final abandonment of Chaco Canyon and the Kayenta and Mesa Verde regions of Arizona and Colorado at $650 \mathrm{cal} \mathrm{yr}$ BP (Dean, 1996). The tree-ring records suggest that winter precipitation decreased over much of the arid Great Basin and Southwest during these droughts. Thus most indigenous populations could not escape the effect of these droughts by relocation.

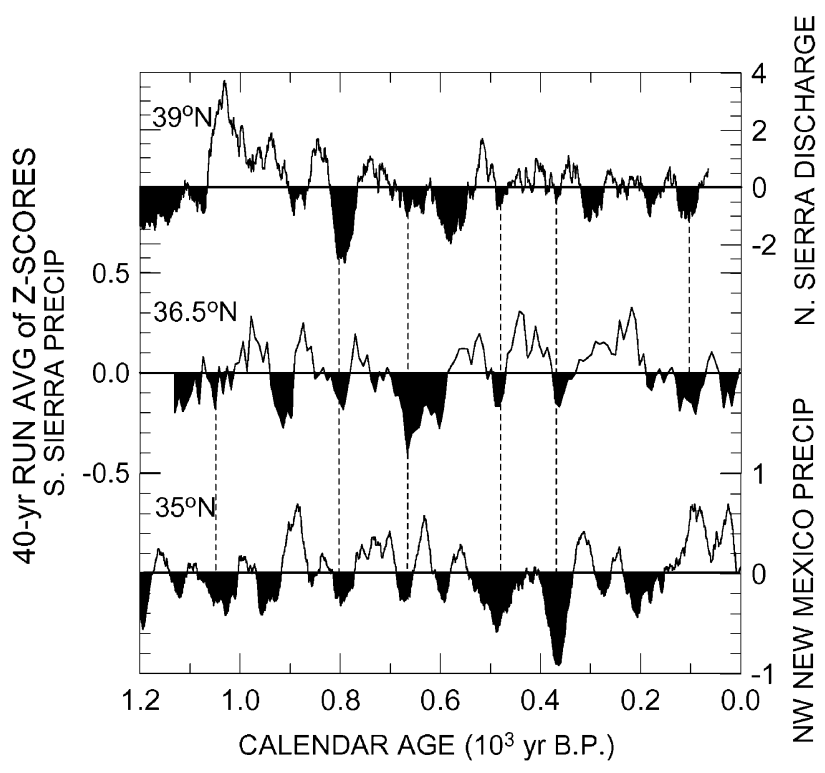

Fig. 28. Comparison of the timing of severe droughts that impacted the northern Sierra Nevada, the southern Sierra Nevada, and northwest New Mexico; 40-yr running averages of the data have been taken. Solid areas indicate times when it was drier than average. Vertical dashed lines indicate droughts that impacted more than one region. Northern Sierra discharge reconstruction from Meko et al. (1998); southern Sierra precipitation reconstruction from Graumlich (1993); and northwestern New Mexico precipitation reconstruction from Grissino-Mayer (1996).

\section{3. $7630-3430$ cal yr BP}

A cubic spline was fit to the $\delta^{18} \mathrm{O}$ and TIC records for PLC98-4; data were extracted every $10 \mathrm{yr}$; and a 40-yr running average was taken (Fig. 29). Approximately, 29 oscillations occur in the $4210-\mathrm{cal}-\mathrm{yr} \delta^{18} \mathrm{O}$ record or, on average, one every $145 \mathrm{yr}$, a periodicity similar to that found for PLC97-1. A comparison of the smoothed $\delta^{18} \mathrm{O}$ and TIC data sets indicates they possess many troughs and peaks in common, suggesting that both records reflect abrupt high-frequency changes in lake size. The long-term trend in TIC mirrors the long-term trend in magnetic susceptibility between 7630 and 3430 cal yr BP, indicating dilution of the TIC fraction. The large magnetic susceptibility values between 7630 and $5600 \mathrm{cal} \mathrm{yr}$ BP indicate that dilution of the TIC fraction with silicate-rich sediments occurred more frequently during this period, implying a period of intense aridity (a time when Pyramid Lake was small and higher concentrations of basin-edge clastics reached the deep-water site). The largest excursions in $\delta^{18} \mathrm{O}$ occurred prior to $6400 \mathrm{cal} \mathrm{yr} \mathrm{BP}$.

The $\delta^{18} \mathrm{O}$ excursion between 7000 and $6400 \mathrm{cal} \mathrm{yr} \mathrm{BP}$ may have been related to one or a combination of hydrologic oscillations occurring during a transition from a very dry to a relatively wet climate. The results of our numerical simulations (blue solid line, Fig. 23) 


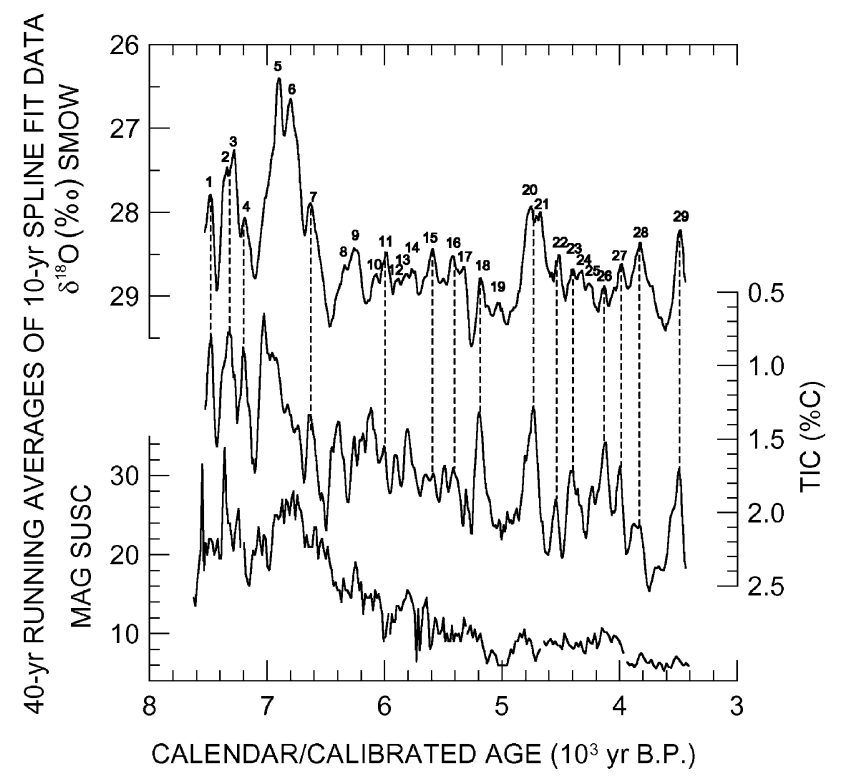

Fig. 29. Smoothed magnetic susceptibility, TIC, and $\delta^{18} \mathrm{O}$ records for PLC98-4. Chemical and magnetic data were smoothed by fitting a cubic spline to data shown in Fig. 24. Data values were taken from the spline fit at 10-yr intervals and a 4-point (40-yr) running average made. Dashed lines indicate times when minima in TIC and $\delta^{18} \mathrm{O}$ coincide. Minima in $\delta^{18} \mathrm{O}$ indicate the termination of a wet period. Wet-dry oscillations have been numbered 1-29.

illustrate such a negative excursion in $\delta^{18} \mathrm{O}$. In this simulation, the depth of Pyramid Lake was set to $40 \mathrm{~m}$, implying that Lake Tahoe and Pyramid Lake were hydrologically closed and that Pyramid Lake was receiving only $\sim 0.30 \mathrm{~km}^{3} \mathrm{yr}^{-1}$ of freshwater input. Increasing the discharge to its mean-historical value $\left(0.70 \mathrm{~km}^{3} \mathrm{yr}^{-1}\right)$ resulted in a negative $4.1 \%$ transient response that lasted $300 \mathrm{yr}$. Alternatively a $19^{\circ} \mathrm{C}$ oscillation in temperature between 7000 and 6400 cal yr BP could have caused the $4.0 \%$ excursion in $\delta^{18} \mathrm{O}$; however, this amount of temperature change seems absurdly large.

Magnetic susceptibility and $\delta^{18} \mathrm{O}$ increase synchronously at $6900 \mathrm{cal}$ yr BP. As was the case for the older part of PLC97-1, we believe that the increase in magnetic susceptibility was due to increased input of reworked magnetite-rich basin-edge sediments to the deep-lake site during a rise in lake level. Therefore, we suggest that a very shallow, hydrologically closed Pyramid Lake experienced a large influx of water between 7000 and $6800 \mathrm{cal} \mathrm{yr} \mathrm{BP}$, causing its $\delta^{18} \mathrm{O}$ value to decrease by $3.8 \%$.

$\delta^{18} \mathrm{O}$ increases in a more-or-less step-like manner across the 700-yr gap between the top of PLC98-4 and the bottom of PLC97-1 (Fig. 24). The mean value of $\delta^{18} \mathrm{O}$ between 6500 and $3430 \mathrm{cal}$ yr BP is $1.6 \%$ less than its mean value between 2740 and $110 \mathrm{calyr}$ BP. The smaller mean middle-Holocene value of $\delta^{18} \mathrm{O}$ could be due to one or more of several phenomena, including the following: (1) colder winter air temperatures during the middle Holocene, (2) warmer autumn air and water temperatures during the middle Holocene (which lower $\delta^{18} \mathrm{O}$ values of the aragonite precipitate), (3) increased rate of overflow of Pyramid Lake during the middle Holocene, or (4) cessation of overflow from Lake Tahoe during the middle Holocene.

On a worldwide basis, the temperature dependence of $\delta^{18} \mathrm{O}$ in precipitation is $\sim 0.7 \% 0^{\circ} \mathrm{C}^{-1}$ (Dansgaard, 1964). Assuming this value is applicable to the Sierra Nevada, a $2.2^{\circ} \mathrm{C}$ decrease in winter air temperature during the middle Holocene would account for the observed 1.6\% shift in $\delta^{18} \mathrm{O}$. A study of the hydrogen isotope composition of tree rings from dendrochronologically dated bristlecone pines from the White Mountains of California demonstrated that moisture taken up by the trees had larger values of $\delta D$ during the middle Holocene (Feng and Epstein, 1994). This implies a corresponding positive shift in the mean $\delta^{18} \mathrm{O}$ value of precipitation, indicating that middle-Holocene winter temperatures were actually warmer rather than colder.

To bring about the observed $1.6 \%$ decrease in Pyramid Lake middle-Holocene $\delta^{18} \mathrm{O}$ values, autumn water temperatures would have to have been $\sim 7.5^{\circ} \mathrm{C}$ higher, implying that increases in air temperature would also have been about the same magnitude. Several studies attest to a warmer middle Holocene (La Marche, 1973; Thompson, 1990; Grayson, 1993) but only La Marche (1973) attempted a calibration of his data, finding that warm-season temperatures increased by $1.0^{\circ} \mathrm{C}$ between 4100 and $3500 \mathrm{cal} \mathrm{yr} \mathrm{BP}$ and by $0.7^{\circ} \mathrm{C}$ at $\sim 900$ cal yr BP in the White Mountains of California The increase in middle-Holocene warm-season temperatures suggested by this study is in the right direction, but it is much less than that implied by the shift in Pyramid Lake $\delta^{18} \mathrm{O}$.

If we assume that late-Holocene climate was similar to the climate of the past $100 \mathrm{yr}$, a wetter middle Holocene could account for the negative shift in $\delta^{18} \mathrm{O}$; e.g., a $17.3 \%$ increase in wetness (from 0.81 to $0.95 \mathrm{~km}^{3} \mathrm{yr}^{-1}$ ) would lower the $\delta^{18} \mathrm{O}$ value of Pyramid Lake water by $1.6 \%$ (Fig. 22). However, a wetter middle Holocene is inconsistent with numerous studies that attest to a drier middle Holocene (Harding, 1965; Lindstrm, 1990; Benson et al., 1991; Thompson, 1992; Benson, 1994a; Benson et al., 1997; Quade et al., 1998; Grayson, 2000). In fact, ages of tree stumps submerged in Lake Tahoe (Fig. 2) suggest that Lake Tahoe may not have overflowed during part of the middle Holocene. If Lake Tahoe ceases spilling during an extended drought, the flow of the Truckee River is reduced to $<0.28 \mathrm{~km}^{3} \mathrm{yr}^{-1}$. As a result of the decreased input, Pyramid Lake suffers closure. Ignoring for the time being the possible effect of increased water temperatures on the $\delta^{18} \mathrm{O}$ value of the carbonate precipitate, shutting off isotopically heavy $(\sim-5.5 \%)$ Lake Tahoe input to the Truckee River 
decreases the steady-state $\delta^{18} \mathrm{O}$ value of Pyramid Lake water by $\sim 0.6 \%$ (orange dashed line, Fig. 23 ) relative to the steady-state value associated with mean-historical discharge (blue solid line, Fig. 23). Thus, closure of Lake Tahoe causes Pyramid Lake $\delta^{18} \mathrm{O}$ values to decrease in the right direction but not enough in magnitude to duplicate the observed difference between middle- and late-Holocene baseline $\delta^{18} \mathrm{O}$ values.

If we assume that fluid inputs to Pyramid Lake were similar during both the late Holocene and the historic period, warmer middle-Holocene autumn temperatures of $\sim 5^{\circ} \mathrm{C}$ are sufficient to explain the $1.0 \%$ decrease in middle-Holocene Pyramid Lake $\delta^{18} \mathrm{O}$ values not accounted for by closure of Lake Tahoe. If, however, the late-Holocene period was, on average, somewhat drier than the historical period, then closure of Lake Tahoe would lead to a larger negative shift in $\delta^{18} \mathrm{O}$. For example, if $V_{\text {in }}$ in the late Holocene was $0.76 \mathrm{~km}^{3}$ then the difference in baseline $\delta^{18} \mathrm{O}$ values of the middle and late Holocene would be $1.3 \%$ (Fig. 23) and middleHolocene autumn temperatures need only have been $\sim 3^{\circ} \mathrm{C}$ warmer than late-Holocene temperatures. In any case, the shift of Pyramid Lake $\delta^{18} \mathrm{O}$ to heavier values during the onset of the late Holocene together with a decrease in Pyramid Lake sediment magnetic susceptibility values indicates that Lake Tahoe was usually closed during the middle Holocene and that drought not tectonic activity was responsible for the trees found submerged beneath the present-day lake.

\section{The magnitude of the middle-Holocene drought}

How dry does it have to become to cause Lake Tahoe to fall below its spill point? The mean-historical volume of water input to Lake Tahoe can be calculated from

$V_{\text {in }}=V_{\text {spill }}+V_{\text {evap }}$,

where $V_{\text {in }}$ is the volume of water input to Lake Tahoe (surface runoff and on-lake precipitation), $V_{\text {spill }}$ is the amount of overflow from Lake Tahoe measured at the Tahoe City gage (Fig. 5), and $V_{\text {evap }}$ is the volume evaporated from the surface of Lake Tahoe.

Historical (1901-1990) measurements of Truckee River discharge at Tahoe City yield a mean value of $0.23 \mathrm{~km}^{3} \mathrm{yr}^{-1}$. The surface area of Lake Tahoe is $499 \mathrm{~km}^{2}$ at its spill point. The annual evaporation rate has been estimated from pan data to be $\sim 0.82 \mathrm{~m} \mathrm{yr}^{-1}$ (McGauhey et al., 1963) and from an energy-balance procedure to be $\sim 1.1 \mathrm{~m} \mathrm{yr}^{-1}$ (Myrup et al., 1979). The calculated values for $V_{\text {evap }}$ thus range from 0.41 to $0.55 \mathrm{~km}^{3} \mathrm{yr}^{-1}$. In the first case, $V_{\text {in }}=0.64 \mathrm{~km}^{3} \mathrm{yr}^{-1}$ and in the second case $V_{\text {in }}=0.78 \mathrm{~km}^{3} \mathrm{yr}^{-1}$. Therefore, when Lake Tahoe does not spill, input to the lake is estimated to be at least $30-36 \%$ less than during the historical period, depending on the value of evaporation used in the calculation.

\section{Timing of Holocene climate change in the Great Basin}

What follows is not intended as a formal subdivision of the Great Basin Holocene; instead, our intention is to draw attention to certain distinct climatic intervals. In the introduction we discussed several studies that indicated the presence of a warm and dry middle Holocene. The various climate indicators that have been used to argue for such an interval do not yield a consistent estimate of its onset (Fig. 30). Some records suggest that the middle Holocene may have begun as early as 9200 cal yr BP, but most records suggest that it began $8000 \pm 300$ and ended $3000 \pm 500 \mathrm{cal} \mathrm{yr} \mathrm{BP}$. Two factors may account for the apparent difference in the onset and termination of the warm dry middle Holocene: climate change may not have occurred synchronously across the Great Basin, and each indicator is an imperfect recorder of climate change, possessing its own response to climate variability. In addition, most of the records used to define the middle Holocene are discontinuous and of low resolution (Fig. 30).

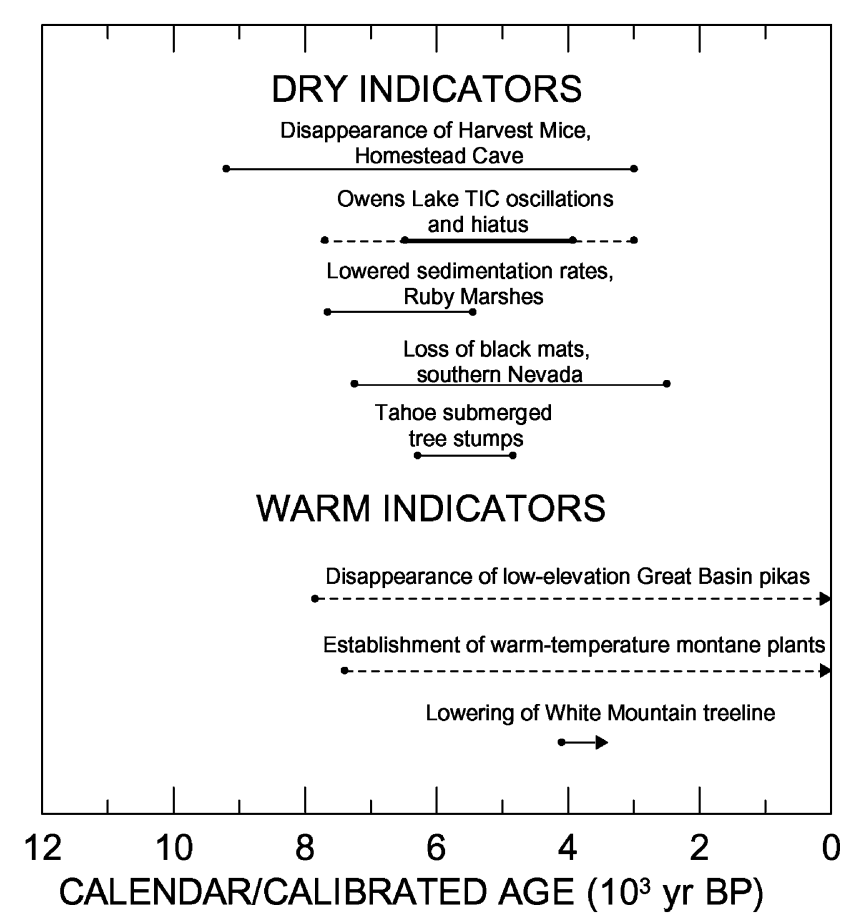

Fig. 30. Middle-Holocene indicators of dry and warm climates. See introduction section for discussion of these sites. Desiccation of Owens Lake indicated by heavy black line. Dashed lines with arrows indicate continuation of warm or dry climate. 
Two high-resolution Holocene-climate records are now available from the Pyramid and Owens lake basins (Fig. 3). These western Great Basin lake records suggest that the Holocene was characterized by five climatic intervals. TIC and $\delta^{18} \mathrm{O}$ records from Owens Lake indicate that the first interval in the early Holocene $(11,600-10,000$ cal yr BP) was characterized by a drying trend that was interrupted by a brief $(200 \mathrm{yr})$ wet oscillation centered at $10,300 \mathrm{cal}$ yr BP. This was followed by a second early-Holocene interval $(10,000-$ 8000 cal yr BP) during which relatively wet conditions prevailed. During the early part of the middle Holocene (interval \#3, 8000-6500 cal yr BP), high-amplitude oscillations in TIC in Owens Lake and $\delta^{18} \mathrm{O}$ in Pyramid Lake indicate the presence of shallow lakes that underwent relatively strong oscillations in hydrologic balance. The shallow nature of the Owens lake is further attested to by the presence of shallow-water oolite deposits and the shallow nature of Pyramid Lake is confirmed by high magnetic susceptibility values (Fig. 3).

During the latter part of the middle Holocene (interval \#4, 6500-3800 cal yr BP), drought conditions dominated and Owens Lake desiccated. Pyramid Lake $\delta^{18} \mathrm{O}$ values indicate that Lake Tahoe was not spilling to the Truckee River and the existence of trees that grew below the sill level of Lake Tahoe during middleHolocene interval \#4 supports the existence of a relatively dry period during this time (Fig. 2). Owens Lake reformed $\sim 3800 \mathrm{calyr} \mathrm{BP}$ and the $\delta^{18} \mathrm{O}$ record from Pyramid Lake indicates that Lake Tahoe rose to its sill level $\sim 3100 \pm 200$ cal yr BP, marking the beginning of the late Holocene (interval \#5). Both Owens and Pyramid lake records are consistent with the estimate of the onset of the late Holocene at $\sim 3000 \mathrm{cal} \mathrm{yr} \mathrm{BP}$; i.e., the shift in $\delta^{18} \mathrm{O}$ and leveling of the TIC and magnetic susceptibility records occur at $\sim 3100 \pm 200$ cal yr BP.

\section{Summary and discussion}

Three lake-size indicators (magnetic susceptibility, TIC, and $\delta^{18} \mathrm{O}$ ) have been applied to sediment cores from Pyramid Lake, Nevada. The decreasing trend in magnetic susceptibility and increasing trend in TIC with time have been used to argue that decreased transport of basin-edge siliciclastic sediments to the center of the lake basin began about 6700 cal yr BP, reflecting an increase in lake depth.

About 3100 cal yr BP, Pyramid Lake $\delta^{18} \mathrm{O}$ experienced a $1.6 \%$ shift to more positive values. Model-based explanations for the shift in $\delta^{18} \mathrm{O}$ values suggest a transition to a colder and wetter climate at this time. Other chemical, biological, archeological, and sedimentological records support this explanation; however, most of these records have not been calibrated to climate parameters and we have not been able to use them to accurately estimate middle- or late-Holocene temperatures. Numerical calculations using a stableisotope hydrologic-balance model suggest that Lake Tahoe did not overflow during much of the middle Holocene, implying that runoff to Lake Tahoe was reduced by at least $30 \%$. Calculations using the temperature-dependent $\delta^{18} \mathrm{O}$ fractionation factor for aragonite-water further suggest that middle-Holocene autumns may have been $\sim 3-5^{\circ} \mathrm{C}$ warmer than lateHolocene autumns.

The earliest part of the PLC98-4 record exhibits the highest-amplitude oscillations in magnetic susceptibility and $\delta^{18} \mathrm{O}$, suggesting that the Pyramid Lake basin was relatively shallow between 7630 and $6500 \mathrm{cal} \mathrm{yr} \mathrm{BP}$, and that large and abrupt changes in the hydrologic balance occurred during this interval. Oscillations in $\delta^{18} \mathrm{O}$ exist throughout the 7630-cal-yr Pyramid Lake record, averaging one about every $150 \mathrm{yr}$. For the PLC97-1 record, we evaluated the derivative of $\delta^{18} \mathrm{O}$ with respect to time, using normalized and smoothed values of this record to show that many droughts were multi-decadal in duration and that intervals between droughts ranged from 80 to $230 \mathrm{yr}$.

Unfortunately, our indicators of change in the hydrologic balance are insufficient to determine the amplitude of its oscillations (intensities of the dry and wet periods). In the Mono Lake basin, Stine (1990a) has shown that droughts reduced the surface area of Mono Lake by $16-32 \%$ of its reconstructed historical (19371979) value during the past $2000 \mathrm{yr}$. If we assume the same relative change in Pyramid Lake surface areas, the most severe drought would have reduced the surface area of Pyramid Lake to $400 \mathrm{~km}^{2}$ and its depth to $88 \mathrm{~m}$. The least severe drought would have resulted in a $500 \mathrm{~km}^{2}$ surface area and a depth of $113 \mathrm{~m}$.

A comparison of lake-surface elevations resulting from these drought scenarios with historical elevations of Pyramid Lake is instructive. As a result of water diversion from the Truckee River, Pyramid Lake fell to a depth of $98.5 \mathrm{~m}$ in the mid-1960s (Fig. 6). If humaninduced diversion of the Truckee River continues at the same rate, Pyramid Lake will eventually reach a steadystate depth of $64 \mathrm{~m}$. This illustrates that human-imposed "drought" will have a greater effect on the size of Pyramid Lake than some of the multidecadal droughts of the past $2000 \mathrm{yr}$.

Urban and agricultural areas in western Nevada and Northern California are dependent on a water supply that originates as winter precipitation in the Sierra Nevada. Historical droughts have lasted less than a decade; however, the drought record presented in this paper indicates the occurrence of droughts that lasted several decades during the past $2740 \mathrm{cal}$ yr. In addition, multicentennial droughts prior to $3430 \mathrm{cal}$ yr may have been so severe as to cause the closure of Lake Tahoe. If and when such droughts reoccur, they will have severe 
consequences for communities in California and Nevada that are dependent on Sierran runoff.

\section{Acknowledgements}

We thank M. Dettinger, K. Redmond, and G. McCabe, for helpful discussions and $\mathrm{H}$. Taylor, $\mathrm{H}$. Grissino-Mayer, A. Blum, and D. Martin for reviews of an earlier version of this manuscript. S. Stine and an anonymous reviewer provided helpful criticisms of this manuscript. H. May designed and oversaw construction of the coring platform. A. Heyvaert and R. Richards took the box cores and A. Heyvaert allowed us to use his $\mathrm{Hg}$ data for PLB98-2. H. Grissino-Mayer and L. Graumlich gave us access to their tree-ring records. J. Dibb performed the ${ }^{137} \mathrm{Cs}$ analyses used in the reconstruction of the historical $\delta^{18} \mathrm{O}$ record. H. Taylor oversaw the $\mathrm{Hg}$ analyses on PLC97-1. A. Taylor processed the core samples and performed the TIC and total carbon analyses. J. Kleppe discovered the tree submerged in Fallen Leaf Lake and P. Catarino collected the ${ }^{14} \mathrm{C}$ samples from Fallen Leaf Lake and Rubicon Point trees. Precipitation and pan evaporation data were supplied by J. Ashby of the Western Regional Climate Center. S. Hostetler provided weekly values of meteorological data for Pyramid Lake; G. Hess provided historical levels for Lake Tahoe; K. Garcia provided compilations of Truckee River discharge at Tahoe City, California; and R. Hunrichs provided annual values of discharge for streams on the western flank of the Sierra Nevada. The Pyramid Lake Paiute Resources group assisted in the collection of the sediment-water interface samples. S. McCabe and E. Hattori provided us access to their textile data base for the western Great Basin.

\section{References}

Alley, R.B., 2000. The Younger Dryas cold interval as viewed from Central Greenland. Quaternary Science reviews 19, 213-226.

Benson, L.V., 1994a. Carbonate deposition, Pyramid Lake subbasin, Nevada: 1. Sequence of formation and elevational distribution of carbonate deposits (tufas). Palaeogeography, Palaeoclimatology, Palaeoecology 109, 55-87.

Benson, L.V., 1994b. Stable isotopes of oxygen and hydrogen in the Truckee River-Pyramid Lake surface-water system. 1. Data analysis and extraction of paleoclimatic information. Limnology Oceanography 39, 344-355.

Benson, LV., Burdett, J.W., Kashgarian, M., Lund, S.P., Phillips, F.M., Rye, R.O., 1996a. Climatic and hydrologic oscillations in the Owens Lake Basin and adjacent Sierra Nevada, California. Science 274, 746-749.

Benson, L.V., Burdett, J., Lund, S., Kashgarian, M., Mensing, S., 1997. Nearly synchronous climate change in the Northern Hemisphere during the last glacial termination. Nature 388, 263-265.

Benson, L.V., Lund, S.P., Smoot, J.P., Kashgarian, M., Burdett, J.W., 2001. Records of climate change from the Owens Lake Basin,
California. In: Hershler, R., Madsen, D., Currey, D. (Eds.), Smithsonian Contributions to Earth Sciences, in press.

Benson, L.V., Meyers, P.A., Spencer, R.J., 1991. Change in the size of Walker Lake during the past 5000 years. Palaeogeography, Palaeoclimatology, Palaeoecology 81, 189-214.

Benson, L.V., Paillet, F., 2002. HIBAL: a hydrologic-isotopic-balance model for application to paleolake systems. Submitted for publication.

Benson, L.V., White, J.W.C., 1994. Stable isotopes of oxygen and hydrogen in the Truckee River-Pyramid Lake surface-water system. 3. Source of water vapor overlying Pyramid Lake. Limnology Oceanography 39, 1945.

Benson, L.V., White, L.D., Rye, R., 1996b. Carbonate deposition, Pyramid Lake subbasin, Nevada: 4. Comparison of the stable isotope values of carbonate deposits (tufas) and the Lahontan lakelevel record. Palaeogeography, Palaeoclimatology, Palaeoecology $122,45-76$.

Broecker, W.S., Walton, A.F., 1959. The geochemistry of ${ }^{14} \mathrm{C}$ in freshwater systems. Geochimica et Cosmochimica Acta 16, 15-38.

Cayan, D.R., Redmond, K.T., Riddle, L.G., 1999. ENSO and hydrologic extremes in the western United States. Journal of Climate 12, 2881-2892.

Cordell, L.S., Gumerman, G.J. (Eds.), 1989. Cultural interaction in the prehistoric Southwest. Dynamics of Southwest Prehistory. Smithsonian Institution Press, Washington, pp. 1-81.

Dansgaard, W., 1964. Stable isotopes in precipitation. Tellus 16, 436468.

Dean, J.S., 1996. Kayenta Anasazi settlement transformations in Northeastern Arizona: A.D. 1150 to 1350. In: Adler, M.A. (Ed.), The Prehistoric Pueblo World, AD 1150-1350. University of Arizona Press, Tucson, pp. 29-47.

De Quille, D., 1889. A History of the Comstock Silver Lode and Mines. Arno Press, New York.

Feng, X., Epstein, S., 1994. Climatic implications of an 8000-year hydrogen isotope time series from bristlecone pine trees. Science 265, 1079-1081.

Galat, D.L., Lider, E.L., Vigg, S., Robertson, S.R., 1981. Limnology of a large, deep, North American terminal lake, Pyramid Lake, Nevada. Hydrobiologia 82, 281-317.

Graumlich, L.J., 1993. A 1000-year record of temperature and precipitation in the Sierra Nevada. Quaternary Research 39, 249255.

Grayson, D.K., 1993. The Deserts Past, a Natural Prehistory of the Great Basin. Smithsonian Institution Press, Washington.

Grayson, D.K., 2000. Mammalian responses to Middle Holocene climatic change in the Great Basin of the western United States. Journal of Biogeography 27, 181-1350192.

Grissino-Mayer, H.D., 1996. A 2129-year reconstruction of precipitation for northwestern New Mexico, USA. In: Dean, J.S., Meko, D.M., Swetnam, T.W. (Eds.), Tree Rings, Environment, and Humanity; Radiocarbon 191-204.

Harding, S.T., 1935. Changes in lake levels in Great Basin area. Civil Engineering 5, 87-90.

Harding, S.T., 1965. Recent variations in the water supply of the Great Basin. Archives Series Report 16, University of California, Berkeley.

Hardman, G., Reil, O.E., 1936. The relationship between tree-growth and stream runoff in the Truckee River Basin, California-Nevada. University of Nevada Agricultural Experiment Station Bulletin 141, University of Nevada, Reno.

Hattori, E.M., 1982. The archaeology of Falcon Hill, Winnemucca Lake, Washoe County, Nevada. Nevada State Museum Anthropological Papers No. 18.

Hecht, A.D., 1983. Drought in the Great Plains: history of societal response. Journal of Climate and Applied Meteorology $22,51-56$

Hughes, M.K., Diaz, H.F., 1994. Was there a medieval warm period, and if so, where and when. Climatic Change 26, 109-142. 
Hughes, M.K., Funkhouser, G., 1998. Extremes of moisture availability reconstructed from tree rings for recent millennia in the Great Basin of western North America. In: Beniston, M., Innes, J.L. (Eds.), The Impacts of Climate Variability on Forests. Springer, New York, pp. 1-81.

La Marche Jr., V.C., 1973. Holocene climatic variations inferred from treeline fluctuations in the White Mountains, California. Quaternary Research 3, 632-660.

Lawrence, D.B., Lawrence, E.G., 1961. Response of enclosed lakes to current glaciopluvial climatic conditions in middle latitude Western North America. Annals of the New York Academy of Science 95, 341.

Leavitt, S.W., 1994. Major wet interval in White Mountains Medieval Warm Period evidenced in ${ }^{13} \mathrm{C}$ bristlecone pine tree rings. Climate Change 26, 299-308.

Lebo, M.E., Reuter, J.E., Rhodes, C.L., Goldman, C.R., 1993. Pyramid Lake, Nevada Water Quality Study 1983-1993. Vol. II. Limnological Description. University of California, Davis.

Lindstrm, S., 1990. Submerged tree stumps as indicators of MidHolocene aridity in the Lake Tahoe basin. Journal of California and Great Basin Anthropology 12, 146-157.

Long, A., Rippeteau, B., 1974. Testing contemporaneity and averaging radiocarbon dates. American Antiquity 39, 205-215.

Lund, S.P., 1996. A comparison of Holocene paleomagnetic secular variation records from North America. Journal Geophysical Research 101, 8007-8024.

McCabe, G.J., Dettinger, M.D., 1999. Decadal variations in the strength of ENSO teleconnections with precipitation in the western United States. International Journal of Climatology 19, 1399-1410.

McGauhey, P.H., Eliassen, R., Lolich, G., Ludwig, H.F., Pearson, E.A., 1963. Climatology and hydrology of Tahoe Basin, comprehensive study on protection of water resources of Tahoe Basin through controlled waste disposal. Lake Tahoe Area Council, California.

Meko, D.M., Baisan, C.H., Hughes, M.K., 1999. In: Wilson, R., Buffaloe, L. (Eds.), Proceedings of the 15th Annual PACLIM Workshop, April 27-30, 1998, State of California, Department of Water Resources, Sacramento, CA.

Mensing, S.A., Southon, J.R., 1999. A simple method to separate pollen for AMS radiocarbon dating and its application to lacustrine and marine sediments. Radiocarbon 41, 1-8.

Myrup, L.O., Powell, T.M., Godden, D.A., Goldman, C.R., 1979a. Climatological estimate of the average monthly energy and water budgets of Lake Tahoe, California-Nevada. Water Resources Research 15, 1499-1508.

O’Neil, J.R., Clayton, R.N., Mayeda, T.K., 1969b. Oxygen isotope fractionation in divalent metal carbonates. Journal of Chemical Physics 51, 5547-5558.

Pyke, C.B., 1972. Some meteorological aspects of the seasonal distribution of precipitation in the western United States and Baja California. University of California Water Resources Center Contribution 139, University of California, Los Angeles.
Quade, J., Forester, R.M., Pratt, W.L., Carter, C., 1998. Black mats, spring-fed streams, and late-glacial-age recharge in the Southern Great Basin. Quaternary Research 49, 129-148.

Redmond, K.T., Koch, R.W., 1991. Surface climate and streamflow variability in the western United States and their relationship to large-scale circulation indices. Water Resources Research 27, 23812399.

Smith, G.H., 1998. The History of the Comstock Lode. Nevada Bureau of Mines and Geology, 328pp.

Smoot, J.P., Benson, L.V., 1998. Sedimentary structures as indicators of paleoclimatic fluctuations: Pyramid Lake, Nevada. In: Pitman, J.K., Carroll, A.R. (Eds.), Modern and Ancient Lake Systems, Guidebook 26. Utah Geological Association, Salt Lake City, UT, pp. 131-161.

Stine, S., 1990a. Late Holocene fluctuations of Mono Lake, eastern California. In: Meyers, P.A., Benson, L.V. (Eds.), Special Issue Paleoclimates: the Record from Lakes, Ocean and Land; Palaeogeography, Palaeoclimatology, Palaeoecology 78, 333-381.

Stine, S., 1990b. Past climate at Mono Lake. Nature 345, 391.

Stine, S., 1994. Extreme and persistent drought in California and Patagonia during mediaeval time. Nature 369, 546-391549.

Stuiver, M., Reimer, P.J., Braziunas, T.F., 1998. High precision radiocarbon age calibration for terrestrial and marine samples. Radiocarbon 40, 1127.

Thompson, R.S., 1990. Late Quaternary vegetation and climate in the Great Basin. In: Betancourt, J.L., VanDevender, T.R., Martin, P.S. (Eds.), Packrat Middens, the Last 40,000 Years of Biotic Change. University of Arizona Press, Tucson, pp. 200-239.

Thompson, R.S., 1992. Late Quaternary environments in Ruby Valley, Nevada. Quaternary Research 37, 1-15.

Townley, J.M., 1980. The Truckee Basin Fishery, 1844-1944. Desert Research Institute Water Resources Center Publication \#43008.

US Geological Survey, 1960. Compilation of records of surface water of the United States through September 1950. 10. The Great Basin. US Geological Survey Water-Supply Paper 1314.

US Geological Survey, 1961-1997. Water resources data for Nevada. US Geological Survey Water-Data Report Series.

Wigand, P.E., 1987. Diamond Pond, Harney County, Oregon: vegetation history and water table in the eastern Oregon Desert. Great Basin Naturalist 47, 427-458.

Wigand, P.E., Mehringer, P.J., 1985. Pollen and seed analyses. In: Thomas, D.H. (Ed.), The Archaeology of Hidden Cave, Nevada. Anthropological Papers of the American Museum of Natural History 61.

Wilson, D., 1992. Sawdust trails in the Truckee Basin, a history of lumbering operations. Nevada County Historical Society, Nevada City, CA.

Woodhouse, C.A., Overpeck, J.T., 1998. 2000 Years of drought variability in the central United States Bulletin. American Meteorological Society 79, 2693-2714. 